\title{
Financial Innovation and Transparency in Turbulent Times
}

\section{Panagiotis Delimatsis*}

The stunning failure of banks put regulatory intervention high on the agenda of governments. Adequate risk monitoring, including by credit rating agencies, measurement and management have proven to be a daunting task, whereas regulation of innovative financial instruments has not brought about adequate disclosure and transparency. After critically reviewing the virtues and pitfalls of financial innovation, this paper offers an analysis of the main transparency initiatives undertaken in the EU and the US in the wake of the crisis to harness various financial innovations that have marked the history of financial markets in the last three decades. In addition, the paper identifies the approach as to financial innovation that the General Agreement on Trade in Services (GATS) of the World Trade Organization (WTO) has adopted in the early ' 90 s and assesses the likely impact of the recent financial crisis on this stance. As the perimeter of regulation grows and countries become more suspicious vis-à-vis home-country financial regulation, trade in financial services will most likely not remain unaffected. 


\title{
Financial Innovation and Transparency in Turbulent Times
}

\author{
PANAGiotis Delimatsis*
}

How did things get so opaque? The answer is 'financial innovation' - two words that should, from now on, strike fear into investors' hearts. ${ }^{1}$

Greater transparency, greater disclosure and stricter risk management by firms has defined financial regulation since the 'deregulatory fervour' of the 80s. This tired trinity failed, whereas calls for greater transparency constitute the mantra of the ignorant. ${ }^{2}$

\begin{abstract}
The stunning failure of banks put regulatory intervention high on the agenda of governments. Adequate risk monitoring, including by credit rating agencies, measurement and management have proven to be a daunting task, whereas regulation of innovative financial instruments has not brought about adequate disclosure and transparency. After critically reviewing the virtues and pitfalls of financial innovation, this paper offers an analysis of the main transparency initiatives undertaken in the EU and the US in the wake of the crisis to harness various financial innovations that have marked the history of financial markets in the last three decades. In addition, the paper identifies the approach as to financial innovation that the General Agreement on Trade in Services (GATS) of the World Trade Organization (WTO) has adopted in the early '90s and assesses the likely impact of the recent financial crisis on this stance. As the perimeter of regulation grows and countries become more suspicious vis-à-vis home-country financial regulation, trade in financial services will most likely not remain unaffected.
\end{abstract}

\section{A. Introductory Remarks}

The global financial crisis of 2008 has raised serious doubts about the correctness of the deregulatory practices of three decades of neoliberal orthodoxy in the banking sector, mostly hailed by developed countries for their adequacy. ${ }^{3}$ At the outset, it appears that a broader consensus is developed around the idea that the current crisis has led to a reassessment of several foundational principles and crucial practices in financial policymaking and the recognition that important changes in the structure and supervision of the global financial system are warranted.

\footnotetext{
* Associate Professor of Law and Tilburg Law and Economics Center (TILEC), Tilburg University, the Netherlands; and Senior Research Fellow, World Trade Institute, Berne, Switzerland. The author would like to thank Thomas Cottier, Hans Degryse, Nils Herger, Costas Stephanou, Michelangelo Temmerman and Wolf Wagner for very enlightening discussions and insights. Financial support by the NCCR International Trade Regulation is gratefully acknowledged. Remaining errors are of the author's alone. Contact: p.delimatsis@uvt.nl.

${ }^{1}$ P. Krugman, 'Innovating Our Way to Financial Crisis', New York Times, 3 December 2007.

${ }^{2}$ The Guardian, 'Greater transparency is the mantra of the ignorant', 19 September 2008.

${ }^{3}$ Cf Emilios Avgouleas, 'The Global Financial Crisis, Behavioural Finance and Financial Regulation: In Search of a New Orthodoxy', 9 Journal of Corporate Law Studies 23 (2009), at 24.
} 
Doubtful securitization practices associated with the housing market and poorly regulated intermediaries were allowed at the edge of the financial system. ${ }^{4}$ Complex financial organizations failed to properly obtain, process, transmit and implement important information pertaining to imminent risk. ${ }^{5}$ Ultimately, the freezing of the inter-bank loan market, lack of suitable disclosure (and monitoring or evaluation thereof) in times of market euphoria and uncertainties about the well-being of the balance sheets of several banks (that the oligopoly-like group of the US-based credit rating agencies did not manage to capture in time $^{6}$ ) led to uncontrolled (but simultaneous and massive) sales of assets. ${ }^{7}$ In response to this turmoil, several countries designed bank rescue programmes. Such programmes have cracked down on recapitalizing banks through purchases of shares by the State; grants of guarantees of bank assets to revitalize the inter-bank market; or even purchases by the State of 'toxic' loan assets. ${ }^{8}$ The mystifying role of the State as another deus ex machina exemplifies a perverse relationship between governments and financial institutions. It further reveals a distorted long-lasting perception of the way a healthy financial system is supposed to function. In addition, the current supervision frameworks failed not only to prevent but also to manage adequately the crisis and prevent it from spreading beyond the United States. Such systems based on national supervision proved incapable to grasp the interconnectedness of the financial markets and institutions nowadays. Such interconnectedness proved to be problematic notably as far as the interaction between the regular banking system and the shadow banking system is concerned, whereby banks may compose parts of the shadow banking chain or buy products issued by shadow banking entities. The crisis brought to the forefront pressing shortcomings that the current cooperation, coordination, consistency and trust between national supervisors exhibit.

More saliently from a trade perspective, the current crisis has thrown into doubt the utility and effectiveness of the current structure of the General Agreement on Trade in Services (GATS). Arguably, the crisis revealed rather brusquely this long-lasting impression regarding the minimal relevance of the current multilateral legal framework regulating trade in services for financial crisis prevention and management. Even if the contribution of the GATS to the crisis was minimal, a pressing normative question remains unanswered: Should the GATS

\footnotetext{
${ }^{4}$ See R. Lastra and G. Wood, 'The Crisis of 2007-09: Nature, Causes, and Reactions' (2010) 13:3 Journal of International Economic Law 531; also M. Hellwig, 'Systemic Risk in the Financial Sector: An Analysis of the Subprime-Mortgage Financial Crisis', Preprints of the Max Planck Institute for Research on Collective Goods Bonn 2008/43, November 2008, p. 10.

5 The tendency of behavioural biases to interfere with accurate thought and analysiswithin complex organizations, thus interfering with the acquisition, analysis, communication and implementation of information both within an organization and between an organization and external parties has been defined as intellectual hazard'. See G. Miller and G. Rosenfeld, 'Intellectual Hazard: How Conceptual Biases in Complex Organizations Contributed to the Crisis of 2008' (2010) 33(2) Harvard Journal of Law and Public Policy 807.

${ }^{6}$ One should recognize here that part of the blame should be borne by the US regulators, which arguably led the creditworthiness judgments of these third-party raters to attain the force of law. See L. White, 'Credit Rating Agencies and the Financial Crisis: Less Regulation of CRAs is a Better Response' Journal of International Banking Law and Regulation (forthcoming)

${ }^{7}$ This type of uncoordinated, but still homogeneous movement towards a given direction (that is, either massive sales or massive buys), the so-called 'herding' is one important feature of financial markets, which exemplifies the absence of pluralism and diversification. See W. Wagner, 'In the Quest of Systemic Externalities: A Review of the Literature' in P. Delimatsis and N. Herger (eds), Financial Regulation at the Crossroads - Implications for Supervision, Institutional Design and Trade (Kluwer Law International, 2011), p. 37; also K. Alexander; J. Eatwell et al, 'Financial Supervision and Crisis Management in the EU', Study prepared for the European Parliament's Committee on Economic and Monetary Affairs, IP/A/ECON/IC/2007-069 (December 2007), pp. 67.

${ }^{8}$ See WTO, 'Financial Services', Background Note by the Secretariat, S/C/W/312, 3 February 2010, para. 118.
} 
play a more critical role in the new shaping of the financial services industry? And if services liberalization remains the central objective of the GATS, has the financial crisis changed our views about the positive effects of liberalization on domestic welfare? Two prominent sources of critique cast doubt on conventional pro-liberalization beliefs: First, Reinhart and Rogoff suggest that the majority of historical crises are preceded by financial liberalization, be it de jure or de facto, whereby new financial entities and instruments remain unregulated or are lightly regulated. ${ }^{9}$ Second, the Commission of Experts on Reforms of the International Monetary and Financial System (the 'Stiglitz Commission') openly criticized the current GATS system as not adequately addressing, inter alia, crisis prevention and management, counter-cyclical and prudential safeguards, or development and inclusive finance. ${ }^{10}$

In the Pittsburgh Summit of September 2009, the G20 Leaders reaffirmed their commitment to 'refrain from raising barriers or imposing new barriers to investment or to trade in goods and services'. They further pledged to minimize any negative impact of domestic policies, including fiscal policy and financial sector support schemes, on trade and investment. ${ }^{11}$ However, it appears that several measures currently in place, including subsidies and 'buy local' requirements adopted in support schemes in the financial sector and stimulus packages, may be challengeable under the World Trade Organization (WTO) rules relating to non-discrimination and transparency. ${ }^{12}$ Even so, it may prove impossible to substantiate a complaint since possibly WTO-inconsistent facilities or guarantees may not have been used; other policies are no longer valid; other measures such as capital injections were of a one-off nature; and other measures included programmes which included conditions that have changed ever since (for instance, debt guarantee schemes). ${ }^{13}$ Furthermore, it appears that WTO Members recognize the urgent nature of the overwhelming majority of the adopted measures and may consider any possible courses of action only after the economies recover.

This paper is structured as follows: Section B critically reviews the peculiarities as well as advantages and drawbacks of financial innovation as depicted notably in the last three decades. Before the recent financial crisis, financial innovation was regarded as inextricably linked with economic growth and aggregate welfare. In the wake of the crisis, criticism as to the utility of financial innovation became more unequivocal. We analyze the current transparency initiatives on several innovative financial products and institutions and critically assess the likely impact of such regulations on the future of financial innovation in Section C. Section D discusses the regulation of global financial services trade in the GATS and the approach of the latter Agreement regarding financial innovation. It suggests that, whereas several of the current regulatory initiatives are susceptible to violate certain obligations that the WTO Members have undertaken, the potential for future disputes will depend on the prudential nature of such domestic measures. Be this as it may, the GATS itself in its current state may only have a limited impact on the future of financial innovation, but it can still serve the major function of the WTO, that is, prevent discrimination among financial service

\footnotetext{
${ }^{9}$ See C. Reinhart and K. Rogoff, This Time is Different: Eight Centuries of Financial Folly (Princeton University Press, 2008).

${ }^{10}$ See United Nations, 'Report of the Commission of Experts of the President of the United Nations General Assembly on Reforms of the International Monetary and Financial System' (hereinafter 'the Stiglitz Commission Report'), 21 September 2009, pp. 103ff, available at: http://www.un.org/ga/econcrisissummit/docs/FinalReport_CoE.pdf (accessed on 20 April 2011).

${ }^{11}$ G20 Pittsburgh Declaration, September 2009.

12 OECD/WTO/UNCTAD, 'Report on G20 Trade and Investment Measures (September 2009-February 2010), March 2010.

${ }^{13}$ Financial Stability Board (FSB), 'Exit from extraordinary financial sector support measures', Note for the G20 meeting of Ministers and Governors on 6-7 November 2009', November 2009.
} 
suppliers. Section E concludes.

\section{B. Financial Innovation Revisited}

\section{Financial innovation, diversification of risk and economic growth}

Empirical studies demonstrate a strong positive link between financial services liberalization and long-term economic growth. ${ }^{14}$ At first blush, it seems that the positive correlation between liberalization and increased welfare still holds in a post-crisis environment. ${ }^{15}$ International trade in financial services, which has become the driving force for progressive liberalization in all services through the GATS, has grown mainly due to important advances in information technology which allowed for cross-border supply. Thus, it is mainly due to financial innovation that trade in financial services has grown in unprecedented levels, notably the cross-border supply of such services (mode 1 in the GATS vernacular). Consolidation through mergers and acquisitions particularly in the banking sector and the creation of 'national champions' in several countries have also given a boost to crossborder trade in financial services. In addition, in Europe significant cross-border consolidation has taken place, driven by several political initiatives to complete the single market for financial services at the EU level. Here again, the objective was to fully reap the advantages that innovative financial products offered to consumption. ${ }^{16}$ All these developments increased the interdependence, convergence and consolidation in the sector and have altered the risk profile of financial institutions.

Financial innovation is an ongoing, dynamic process that entails the creation and subsequent popularization of new financial instruments, as well as new financial technologies, institutions and markets. ${ }^{17}$ It appears to be driven by investor demand for particular patterns of cash flows. ${ }^{18}$ Financial innovation experienced steady growth in recent years and arguably transformed the once relationship-focused financial intermediaries. Much like financial systems, financial innovations serve six main functions. They allow: (a) moving funds across time and space (eg savings accounts); (b) pooling of funds (eg Mutual funds); (c) risk management (eg futures and options); (d) extracting information to support financial decisionmaking (eg products for the assessment of default probabilities); (e) confronting moral hazard and information asymmetry problems (eg venture capital); and (f) facilitating payments (debit and credit cards). ${ }^{19}$ In this respect, financial innovation increases welfare. ${ }^{20}$ However, one should also take into account the pervasive nature of financial fragility, as experienced by the

\footnotetext{
${ }^{14}$ F. Eschenbach, J. Francois and L. Schuknecht, 'Financial Sector Openness and Economic Growth', in S. Claessens and M. Jansen (eds), The Internationalisation of Financial Services: Issues and Lessons for Developing Countries (Kluwer Law International, 2000); also A. Mattoo, R. Randeep and A. Subramanian, 'Measuring Services Trade Liberalization and Its Impact on Economic Growth: An Illustration', 21 Journal of Economic Integration (2006) 64.

15 For reference to specific studies, see B. Hoekman and A. Mattoo, 'Services Trade Liberalization and Regulatory Reform: Re-invigorating International Cooperation', CEPR Discussion Paper No 8181, January 2011.

${ }^{16}$ Take the case, more recently, of the Payment Services Directive at the European level.

17 J. Lerner and P. Tufano, 'The Consequences of Financial Innovation: A Counterfactual Research Agenda', NBER Working Paper No 16780, February 2011, p. 6.

${ }^{18}$ N. Gennaioli; A. Shleifer; and R. Vishny, 'Neglected Risks, Financial Innovation, and Financial Stability' NBER Working Paper No 16068, June 2010.

${ }^{19}$ Lerner and Tufano, above note 17, p. 8.

${ }^{20}$ See F. Allen and D. Gale, Financial Innovation and Risk Sharing (MIT Press, 1994).
} 
financial crisis of 2007-08.

Financial innovation has arguably transformed the way finance functions. ${ }^{21}$ Its pace has profoundly changed after the July 1998 appellate decision in State Street Bank and Trust v. Signature Financial Group, ${ }^{22}$ which dealt with the question as to whether a software programme used to determine the value of mutual funds was patentable. Ultimately, the Court of Appeals for the Federal Circuit, i.e. the centralized appellate court for patent cases, unequivocally accepted the patentability of business methods, which has been perceived to also include financial patents. ${ }^{23}$ However, litigation in the area of financial patents has also increased in a rather disproportionate manner, targeting larger firms. ${ }^{24}$

In a pro-innovation euphoria with a manifest contra-regulation touch, novel financial products or financial process innovations were regarded as essential for improved capital raising, diminution of cost and diversification/distribution of risks. ${ }^{25}$ Financial innovation has been characterized as an 'engine of economic growth' generating positive externalities from which consumption and investment benefited. ${ }^{26}$ It also had an undeniable positive impact on those firms (such as biotechnology or sustainable energy start-ups) which, in the absence of innovative financial entrepreneurs, would not be able to raise capital. ${ }^{27}$ Indeed, financial innovation has been inextricably linked with technical innovation. When high-risk high-profit entrepreneurial endeavours were at stake and in the absence of traditional financial tools which would adequately evaluate and manage risks, innovative financial products were developed to allow for appropriate risk diversification and diffusion.

Without the existence of venture capital firms to evaluate and fund high-tech entrepreneurs, much of the contemporary technological innovation would not be feasible. The same goes with investment banks and large projects, such as those relating to infrastructure. Nowadays, unless the financial sector innovates regularly to develop new screening methodologies to properly assess and subsequently finance projects of technological innovation, technological innovation cannot continue. Thus, at least viewed from this angle, there is a close relationship between financial and technological innovation - and of those two with economic growth. ${ }^{28}$ For instance, it was found that venture capital in the United States was responsible for some $10 \%$ of US industrial innovation in the period 1983-1992, even though it represented on average not more than $3 \%$ of corporate R\&D in that period. ${ }^{29}$

Financial innovation has also been concerned with improving the technological means of supplying financial services. Thus, just as with product innovation, financial innovation

${ }^{21}$ R. Litan, 'In Defense of Much, But Not All, Financial Innovation', Brookings Institution, February 2010, p. 2.

22149 F.3d 1368, 1375 (Fed. Cir. 1998).

${ }^{23}$ See R. Merges, 'The Uninvited Guest: Patents on Wall Street' (2003) 88:4 Federal Reserve Bank of Atlanta Economic Review 1.

${ }^{24}$ J. Lerner, 'The Litigation of Financial Innovations', Harvard Business School Working Paper 09-027. 2008.

${ }^{25}$ J. Lerner, 'The New New Financial Thing: The Origins of Financial Innovations', 79 Journal of Financial Economics (2006) 223.

${ }^{26}$ R. Metron, 'Financial Innovation and Economic Performance' 4 Journal of Applied Corporate Finance (1992) 12.

${ }^{27}$ S. Michalopoulos; L. Laeven; and R. Levine, 'Financial Innovation and Economic Growth', NBER Working Paper No 15356, September 2009. See also M. O'Sullivan, 'Finance and Innovation' in J. Fagerberg; D. Mowery; and R. Nelson (eds), The Oxford Handbook of Innovation (Oxford University Press, 2005), p. 240.

${ }^{28}$ R. Levine and S. Michalopoulos, 'Financial Innovation and Endogenous Growth', 1 April 2009, available at: http://notizie.unimo.it/campusfile/file/ECO_DEP/file26331.pdf.

${ }^{29}$ S. Kortum and J. Lerner, 'Assessing the Contribution of Venture Capital to Innovation' (2000) 31 RAND Journal of Economics 674. 
incorporates the invention of a financial product or process but also the diffusion of these. ${ }^{30}$ IT technologies allowed for office automation and thus better organization of financial service suppliers. In the area of securities, financial innovations have altered the nature of such financial services, notably in the $20^{\text {th }}$ century. ${ }^{31}$ Such means (for instance, the Automatic Teller Machine-ATM, which is a mechanical financial innovation) have also improved the level of services towards the final consumer. Furthermore, such advances have also facilitated the splitting up of several financial activities, which was destined to become the global phenomenon of outsourcing. Processing and management of client data, research, or clearing and settlement of payments can be supplied nowadays in the four corners of the globe in a very streamlined and expedited manner. In addition, due to technological advances, electronic trading is revolutionalized in that trades travel at about $90 \%$ of the speed of light. ${ }^{32}$

Having said this, financial innovation has typically been about the improvement of existing financial products, ie prior products beget the next ones. Merton illustrated the dynamics of financial innovation by using the term 'financial-innovation spiral'. According to Merton ${ }^{33}$

As products such as futures, options, swaps and securitized loans become standardized and move from intermediaries to markets, the proliferation of new trading markets in those instruments makes feasible the creation of new custom-designed financial products that improve 'market completeness'. To hedge their exposures on those products, their producers, financial intermediaries, trade in these new markets and volume expands; increased volume reduces marginal transaction costs and thereby makes possible further implementation of more new products and trading strategies by intermediaries, which in turn leads to still more volume. Success of these trading markets and custom products encourages investment in creating additional markets and products, and so on it goes, spiraling towards the theoretically limiting case of zero marginal transaction costs and dynamically-complete markets. (emphasis added)

A possible taxonomy of financial innovations groups them as new products (eg subprime mortgages, derivatives, or stock-market index funds) or services (eg internet banking); new production processes (eg credit scoring; new means of processing and pricing transactions); or new organizational forms (eg Internet-only, 'virtual' banks). ${ }^{34}$ Crucially, then, financial innovation has not only been about innovative products, but also new processes such as asset securitization $^{35}$ and management types. Ratione personae, another possible taxonomy would classify financial innovations between those benefitting consumers (payments, savings and consumer-lending innovations) and those primarily aimed at the better functioning of

\footnotetext{
${ }^{30}$ For entities that try to catch-up, such as technologically laggard firms, underdeveloped regions or developing countries, diffusion is the most important part of the innovation process, as it allows them to benefit from innovation. See B. Hall, 'Innovation and Diffusion' in Fagerberg; Mowery and Nelson (eds), above note 27, at 460 .

${ }^{31}$ See P. Tufano, 'Securities Innovations: A Historical and Functional Perspective' (1995) 7 Journal of Applied Corporate Finance 90.

32 Jason Palmer, 'Stock trades to exploit speed of light, says researcher', 23 March 2011, available at: http://www.bbc.co.uk/news/science-environment-12827752 (visited 20 April 2011).

${ }^{33}$ R. Merton, 'A Functional Perspective of Financial Intermediation' (1995) 24 Financial Management 23, at 27.

${ }^{34}$ See W. Scott Frame and L. J. White, 'Technological Change, Financial Innovation, and Diffusion of Banking' in A. Berger; P. Molyneux; and J. Wilson (eds), The Oxford Handbook of Banking (Oxford University Press, 2010), at 488 .

${ }^{35}$ Under this category, one would find collateralized debt obligations (CDOs). See also A. Ashcraft and T. Schuermann, 'Understanding the Securitization of Subprime Mortgage Credit' (2008) Federal Reserve Bank of New York Staff Study No 318.
} 
financial institutions, institutional investors and firms (lending products to raise capital and innovations relating to the diversification and allocation of risk). ${ }^{36}$

Important financial innovations that also played a central role in the current crisis relate to securitized credit. Securitization (that is, the transformation of assets that are difficult to value into tradeable securities), in itself is regarded as a positive financial innovation and a critical component of repairing credit intermediation in the wake of the crisis. ${ }^{37}$ However, even if securitized credit has been a central feature of modern finance since the early $20^{\text {th }}$ century, ${ }^{38}$ the securitized credit model has profoundly changed (starting in 1990s) to satisfy the demand for better yields, thereby increasing leverage within the financial system which ultimately led to the current turmoil. ${ }^{39}$ Indeed, securitization is deemed to have been an important component of the so-called 'shadow banking system' where market-based intermediaries, which resembled traditional banking institutions without however been regulated in a similarly heavy way, became a source of high leverage and systemic risk. ${ }^{40}$

As noted earlier, technological advances, structural changes or the introduction of new industry structures and business models in the financial sector have given a boost to the development or cross-border trade in financial services. ${ }^{41}$ Furthermore, they ameliorated the conduct of business in this sector in terms of costs and efficiency. Innovating in the financial sector through extensive financial engineering has also been an incentive for financial service providers in order to maximize profit vis-à-vis their competitors. ${ }^{42}$ Indeed, financial innovation can generate monopoly rents for the innovating provider, just as technological innovation yields monopoly rents for the entrepreneurs. ${ }^{43}$ For instance, the creation of a financial method allowing the more precise assessment of the viability of a given project gives a valuable first-mover advantage to its creator. ${ }^{44}$

First-mover advantages in financial innovation are not necessarily related to exorbitant profits; it is rather the expertise (which can led to lower costs) and the reputation for expertise among potential competitors (for instance, issuers) that can be obtained through innovation. ${ }^{45}$ This expertise involves the ability to exploit the properties of the innovative product to the benefit of the developer/issuer; the ability to price the product in the market accurately (which does not necessarily lead to higher prices when compared to imitators; quite the contrary, as

\footnotetext{
${ }^{36}$ Litan, above note 21.

37 See IMF, Global Financial Stability Report - Durable Financial Stability: Getting There from Here, April 2011, p. 27; also K. Dam, 'The Subprime Crisis and Financial Regulation: International and Comparative Perspectives' (2010) 10 Chicago Journal of International Law 1.

${ }^{38}$ It was estimated that, by 2006 , about $55 \%$ of all motgages, $45 \%$ of all credit card loans, and $16 \%$ of nonrevolving loans (which are predominantly auto-installment loans) were securitized. See R. Rosen, 'The Role of Securitization in Mortgage Lending', (2007) Chicago Fed Letter: Essays on Issues.

${ }^{39}$ See Report of the the High-Level Group on Financial Supervision in the EU chaired by Jacques de Larosière (the 'de Larosière Report'), 25 February 2009, p. 7.

${ }^{40}$ Avgouleas, above note 3, p. 26; and Dam, above note 37, p. 24; also FSB, 'Shadow Banking: Scoping the Issues', Background Note of the Financial Stability Board, 12 April 2011.

${ }^{41}$ S. Claessens, 'Regulatory Reform and Trade Liberalization in Financial Services', in A. Mattoo and P. Sauvé (eds), Domestic Regulation and Service Trade Liberalization (Oxford University Press, 2003).

${ }^{42}$ See D. Duffie and R. Rahi, 'Financial Market Innovation and Security Design: An Introduction' (1995) 65 Journal of Economic Theory 8.

${ }^{43}$ Economic theory suggests that competition does promote innovation. See the seminal work by P. Aghion; N. Bloom; R. Blundell; R. Griffith; and P. Howitt, 'Competition and Innovation: An Inverted-U Relationship' (2005) The Quarterly Journal of Economics 701.

${ }^{44}$ Levine and Michalopoulos, above note 28.

${ }^{45}$ P. Tufano, 'Financial Innovation and First-Mover Advantages' (1989) 25 Journal of Financial Economics 213.
} 
they may use lower prices); and knowledge of the market of potential investors in the product. However, the literature on financial innovation reveals that a strong relationship exists between innovation and market share. Innovators become larger the more they innovate.

Importantly, for quite a considerable period of time, financial innovation seems to have been erroneously associated with the size of a given financial institution. This may be also because research on innovation in manufacturing was considered as relevant for financial innovation as well. However, it has become clear that financial innovation has its own dynamics and thus needs to be examined on its own right. ${ }^{46}$ Thus, it was demonstrated that small firms are more innovative than the bigger financial institutions. ${ }^{47}$ Financial innovation, though, can hamper the profitability of a firm in the short run, although this trend is corrected in subsequent years, which suggests that the sustainability of a firm can be severely jeopardized for a certain period until returns actually start appearing in the balance sheet. ${ }^{48}$

\section{Financial Innovation in the Wake of the Crisis}

Post-crisis, the financial system is called upon to re-evaluate securitization as a source of funding rather than credit risk transfer. ${ }^{49}$ As for management, one notorious method widely used as the main tool in bank risk management was value-at-risk (VaR), a mathematically sophisticated tool allowing the identification of forward-looking risk by observing past patterns of price movement. ${ }^{50}$ In this case, one can see to what extent financial innovations can have dramatic effects to third parties. One of the main features of the current crisis was a sudden and sharp reduction of credit availability, with an inevitable impact on interest rates, which hampered access to credit for the most vulnerable small businesses. Central banks, on the other side, essentially overestimated the role of price stability for economic growth and financial stability and, in turn, underestimated the impact of financial innovations on risk and liquidity management in financial markets. ${ }^{51}$ Such negative externalities to actors and businesses which were not involved in the mortgage market exemplify the peculiarities of financial innovation and dramatically demonstrate their role in generating systemic risk in a highly interconnected financial system.

Financial innovation, notably in the area of structured finance and as a possible source of contagion transcending borders, ${ }^{52}$ has also accentuated the challenges for regulators and supervisors. ${ }^{53}$ For the latter, a central challenge in the exercise of their function was how to deal with such complex instruments the virtues of which the industry has been praising and extensively using. Information asymmetries do not only exist in the relationship between financial service providers and consumers, but also between providers and regulators/supervisors. In other words, the existence of the necessary savvy within the

\footnotetext{
${ }^{46}$ Lerner and Tufano, above note 17, p. 3.

${ }^{47}$ But see W. Scott Frame and L. White, 'Empirical Studies of Financial Innovation: Lots of Talk, Little Action?', Federal Reserve Bank of Atlanta Working Paper 2002-12, 2002.

${ }^{48}$ Lerner, above note 25 .

${ }^{49}$ Cf. FSA, 'Prudential Risk Outlook 2011', p. 43.

${ }^{50}$ In a retrospective, it appears that not only did VaR not warn of rising risk, but it actually was showeing that risk was low. See Financial Services Authority, 'The Turner Review - A regulatory response to the global banking crisis' (the 'Turner Review'), March 2009, p. 45.

${ }^{51}$ See the Stiglitz Commission Report, p. 35.

${ }^{52}$ Cf H. Degryse; M. Ather Elahi and M. Fabiana Penas, 'The Impact of Cross-Border Exposures on Financial Contagion' in Delimatsis and Herger (eds), above note 7.

${ }^{53}$ C. E. Barfield (ed), International Financial Markets: Harmonization versus Competition (Washington, DC: AEI Press, 1996).
} 
competent supervisory authorities could not be taken for granted, as the Madoff scandal exemplified with respect to the limits of the oversight of Securities and Exchange Commission (SEC) ${ }^{54}$ Financial globalization and conglomeration and an unparallel growth of financial institutions offering multiple services across borders have negatively affected the ability of any public authority to keep track of tectonic changes in the financial sector.

Indeed, the increasing integration of the global financial system, a powerful free-market or 'hands-off' orthodoxy and the unprecedented blurring of jurisdictions that may cause overlaps (that is, when two different regulators or supervisors intervene simultaneously) or gaps (that is, when the same regulators and supervisors believe that their peers in another country will intervene, but in fact none of them does) has perplexed regulators even in the most advanced economies, as exemplified by the latest credit crunch. Traditional distinctions between banks, insurance companies, and brokerage or investment firms have gradually vanished into thin air in the continuous quest for additional earnings. ${ }^{55}$ For several years, the self-correcting ability of the financial markets was acclaimed. Financial innovation was in fact regarded as one of the driving forces of self-regulation. ${ }^{56}$ Thus the concept of market discipline appeared and played an important role on prudential matters as a complementary buffer to the supervision of the public authorities, e.g. by alleviating some of the information asymmetries that are inherent in the financial sector. ${ }^{57}$

In addition, and quite paradoxically, the so-called 'too-big-to fail' concept added to the moral hazard issues associated with financial services supply by large financial institutions. A vicious circle is created which is not corrected by the current effort to create a list of 'systemically important financial institutions' (SIFIs). ${ }^{58}$ This is so because the very presence of a company in this list can be an indication that governments will most likely make every effort to bail out such an institution in the case of collapse, thereby giving the wrong signal to such institutions, which have no incentive to strive for responsible risk taking. Furthermore, such distinction among institutions would require the boundary to be effectively policed, whereas institutions may still try to game the system. It also loses sight of the fact that the systemic importance of an institution will vary along a scale of different degrees of systemic importance. Defining ex ante a systemically important institution is difficult and criteria may change over time, depending on the type of crisis. ${ }^{59}$ One of the proposals that will arguably more effectively with systemic risks is the establishment of an effective and expeditious resolution scheme for failed institutions, not only at the national level, but also at the global level for SIFIs that are globally active. ${ }^{60}$

${ }^{54}$ In a similar vein, see Swiss Financial Market Supervisory Authority (FINMA), 'Finanzmarktkrise und Finanzmarktaufsicht', 14 September 2009, at 12-13 and 21-22, quoted in C. Kaufmann and R. Weber, 'The Role of Transparency in Financial Regulation' (2010) 13:3 Journal of International Economic Law 779, at 789.

${ }^{55}$ WTO, above note 8.

${ }^{56}$ C.Stefanadis, 'Self-Regulation, Innovation, and the Financial Industry' (2003) 23:1 Journal of Regulatory Economics 5. The author finds that, whereas self-regulation reduces price transparency, it overall raises social welfare by encouraging innovation.

${ }^{57}$ Market discipline had explicitly formed part of the Basel II framework. See C. Stephanou, 'Rethinking Market Discipline' in Delimatsis and Herger (eds), above note 7.

${ }^{58}$ Cf. IMF; BIS; and FSB, 'Guidance to Assess the Systemic Importance of Financial Institutions, Markets and Instruments: Initial Considerations', Report to G20 Finance Ministers and Central Bank Governors, October 2009.

${ }^{59}$ Cf. CEBS, 'CEBS' response to the European Commission's Communication on an EU Framework for CrossBorder Crisis Management in the Banking Sector, CEBS 2009309 rev2-FINAL, 19 January 2010, para. 18.

${ }^{60}$ Cf. FSB, 'Reducing the moral hazard posed by systemically important financial institutions - FSB Recommendations and Time Lines', 20 October 2010. The G20 leaders endorsed this policy framework at the Seoul Summit on 11-12 November 2010. 
Being a driving force behind the rapid development of financial services at a global level, certain forms of financial innovation are to blame for the recent financial turmoil. ${ }^{61}$ Such innovations, for instance, those relating to credit risk modelling, were actually backed by the Basel II rules. ${ }^{62}$ However, they accentuated information asymmetry problems, whereas the increased complexity made risk assessment harder and thus risk management more difficult. More generally, one of the most deleterious features of very recent financial innovation was that it was focused too much on accounting and tax and regulatory arbitrage. Nevertheless, these very regulations that innovative products were aiming to circumvent were designed to ensure the efficiency and stability of the financial system.

Due to their dynamic nature, the consequences of financial innovations can change over time, as their underlying structure or use may be transformed by subsequent users of those innovations. Essentially, misrepresentation of novel products to end-users or inadequate management of these products' credit or market risks led to undesirable outcomes. This was partly due to regulators' failure to act in a proactive manner or react promptly in regulating innovative financial instruments. ${ }^{63}$ The crisis has shown how crucial a flexible forwardlooking perspective is in order to capture mutations in credit intermediation that are susceptible to put the financial system in jeopardy. At the same time, however, one cannot but recognize that financial legislation has never really involved any elements revealing a consistent or logical system of legislation. ${ }^{64}$

\section{State Intervention and the 'Regulatory Dialectic'}

Whereas financial innovation is often a response to regulation, ${ }^{65}$ in most instances, financial innovation has got dramatically ahead of regulation. What has been termed as 'regulatory dialectic' in finance seems to explain this type of lag, which is mainly motivated by the willingness of the regulatees to constantly avoid or circumvent regulation in financial services. ${ }^{66}$ In theory, ex ante regulation of an innovative product may be regarded as counterproductive thereby delaying innovation. The regulator would rather intervene once the sideeffects of the innovation become apparent. In practice, however, the complexity of a given product (take, for instance, the unbundling of mortgage banking that became possible due to financial innovation and which was at the heart of the recent financial crisis), along with agency problems and supervisory forbearance, may delay regulatory intervention. ${ }^{67}$ In

\footnotetext{
${ }^{61}$ M. Pagano and P. Volpin, 'Securitization, Transparency and Liquidity', CEPR Discussion Paper No DP7105 (2008).

62 See D. Marques Ibanez and M. Scheicher, 'Securitization - Instruments and Implications' in Berger; Molyneux; and Wilson (eds), above note 34, at 601.

63 The experience-good-akin nature of new financial products is very informative on this score. See G.A. Akerlof, 'The Market for "Lemons": Quality Uncertainty and the Market Mechanism' (1970) 84 The Quarterly Journal of Economics 3.

64 Cf. C. Tietje and M. Lehmann, 'The Role and Prospects of International Law in Financial Regulation and Supervision’ (2010) 13:3 Journal of International Economic Law 663, at 665.

${ }^{65}$ M. H. Miller, 'Financial Innovation: The Last Twenty Years and the Next', (1986) 21 Journal of Financial and Quantitative Analysis 459.

${ }^{66}$ E. Kane, 'Competitive financial reregulation: an international perspective' in R. Portes and A. Swoboda (eds), Threats to International Financial Stability (Cambridge University Press, 1987), p. 114.

${ }^{67}$ However, it was argued recently that even such intervention vis-à-vis the product may be challenging, a regulator can and should still proceed to regulate at an early stage the use of such products by undercapitalized banks. See X. Freixas and B. Parigi, 'Rules vs. discretion in times of financial innovation', paper presented at a conference on 'Internationalization of Services: Competition and Regulatory Interaction in Europe', 25-27 June 2009, available at: http:/www.cepr.org/meets/wken/2/2404/papers/.
} 
addition, because of the dynamic nature of financial innovation and the interconnectedness of the financial system, a minimal delay by the regulator may be sufficient to allow the display of the negative effects of maltreat of an innovative product. The rise of securitization and hedge funds and the widespread use of offshore special purpose vehicles have driven financial globalization. The dark side of the latter has notably been extensive regulatory arbitrage and an unprecedented exposure to products the underlying values of which (and the ensuing risk thereof) were largely unknown to the foreign investors. ${ }^{68}$ Foreign exchange futures, swaps and options; interest-rate futures, swaps, options and forwards; commodity futures, swaps and options became part of the everyday vocabulary of speculators looking for additional sources of income.

Governments have thus been called upon to find the line of equilibrium between the promotion of sound regulation of financial services and the further development of financial innovation, notably in the last thirty years. The level of sophistication of current financial innovations makes this endeavour a very delicate exercise. This may actually leed governments and regulatory authorities to react to any challenges relating to financial innovations not in a pro-active manner, but rather once the problems come to the surface, that is, rather late. Admittedly, financial regulation has more often than not been a by-product of or reaction to crises or conflicts. ${ }^{69}$ However, it is argued that, in the current stage of financial development, a lot more is at stake if regulatory intervention is to affect the pace of financial innovation. Indeed, stringent and inflexible rules may act as a disincentive against the production of innovative financial products and institutions. It has been suggested that a new approach is needed in this complicated area of rulemaking. Because financial innovation is inextricably linked with globalized financial markets, regulatory co-operation, co-ordination and prompt information sharing are essential in an interdependent global financial matrix. ${ }^{70}$ One of the lessons of the present financial meltdown is that financial regulation cannot remain essentially national. The G20 London Summit Declaration also goes along these lines.

When it comes to banks, the Basel Committee on Banking Supervision (BCBS) came up with new global standards in December 2010, commonly referred to as 'Basel III', to strengthen the resilience of banks and the global banking system. ${ }^{71}$ This regime should be fully effective by 2019. These standards attempt to implement previous recommendations by several groups such as the de Larosière report or the Turner Review that examined the causes of the crisis and the challenges that it raised notably when it comes to higher capital requirements both in terms or quantity and quality to ensure that banks are better-equipped to absorb losses like those relating to the global financial crisis. ${ }^{72}$

Furthermore, Basel III requires better risk coverage, notably with regard to capital market activities. Importantly, Basel III foresees the establishment of an internationally harmonized

\footnotetext{
${ }^{68}$ Cf. P. Lane and G. Maria Milesi-Ferretti, 'The Drivers of Financial Globalization' (2008) 98:2 American Economic Review 327.

${ }^{69}$ See C. Goodhart and R. Lastra, 'Border Problems' (2010) 13:3 Journal of International Economic Law 705, at 711.

${ }^{70}$ This is notably the case in areas such as crisis prevention, management and resolution. See A. Mattoo and A. Subramanian, 'From Doha to the Next Bretton Woods - A New Multilateral Trade Agenda' (2009) 88:1 Foreign Affairs 15.

${ }^{71}$ See BIS, 'Basel III: A global regulatory framework for more resilient banks and banking systems', December 2010; also previously, BIS, 'The Basel Committee's response to the financial crisis: report to the G20', October 2010 .

${ }^{72}$ Higher capital and liquidity requirements are expected to lead to a reduction, albeit minimal, of GDP. See Macroeconomic Assessment Group, 'Assessing the macroeconomic impact of the transition to stronger capital and liquidity requirements - Interim Report', August 2010.
} 
leverage ratio to constrain excessive risk-taking and to serve as a backstop to the risk-based capital measure as well as various capital buffers which are to be built up in good times and can be use in stress periods, including a capital conservation buffer and a countercyclical buffer to protect the banking sector from periods of excessive credit growth. The new regulatory framework for banks also introduces minimum global liquidity standards consisting of a short term liquidity coverage ratio coupled with a longer term, structural net stable funding ratio. In addition, Basel III brings forward proposals for a more solid risk management, covering areas such as corporate governance, off-balance sheet exposures and securitization activities or compensation practices. It also calls for better supervision - for instance, when the assessment of the adequacy of a bank's liquidity risk management framework and its level of liquidity is at stake - and effective cooperation among supervisors, but also central banks. Crucially, the BCBS also came forth with good practice principles on supervisory colleges, ${ }^{73}$ alluding to the need for coherent cross-border supervision of international banking institutions with a view to also improving financial stability at the macroprudential level.

With respect to enhanced transparency, the new framework requires that all elements of capital required be disclosed. To improve short- and long-term transparency, the new regulatory framework establishes two minimum standards for funding liquidity: the Liquidity Coverage Ratio (LCR) and the Net Stable Funding Ratio (NSFR), which aim to ensure that banks can survive an acute stress scenario of one month and one year, respectively. It is for national supervisors to ensure that the parameters used in their jurisdiction are transparent and outlines in their regulations. To date, the BCBS put on consultation its proposed Pillar 3 disclosure requirements for remuneration practices. ${ }^{74}$

The IMF has suggested that the stringency of the new framework agreed upon at the BCBS may put several banks, notably in Europe, in a rather difficult situation, which may ultimately lead to the resolution of weak, that is, undercapitalized, banks, as raising capital from public sources is not a sustainable solution. This may, inter alia, lead to substantial consolidation in the banking sector. ${ }^{75}$ The IMF' proposes a more holistic approach (See Figure 1) with respect to banking reform, which, by its nature, goes beyond the BCBS' new regulatory framework relating to banking and makes reference to broader regulatory reforms that governments should endeavour to implement.

Figure 1. Policy Solutions to the Challenges of the Banking Sector

\footnotetext{
${ }^{73}$ For the parallel work at EU level, see 'the ten principles for the functioning of supervisory colleges agreed on by the Committee of European Banking Supervisors (CEBS) and the Committee of European Insurance and Occupational Pensions Supervisors (CEIOPS), together with their Interim Working Committee on Financial Conglomerates (IWCFC) in January 2009. In December 2010 the CEBS and the CEIOPS came up with seven recommendations for supervisory colleges of financial conglomerates.

${ }^{74} \mathrm{BCBS}$, 'Pillar 3 disclosure requirements for remuneration - Consultative Document', December 2010.

${ }^{75}$ See IMF, above note 37 , pp. $11 \mathrm{ff}$.
} 


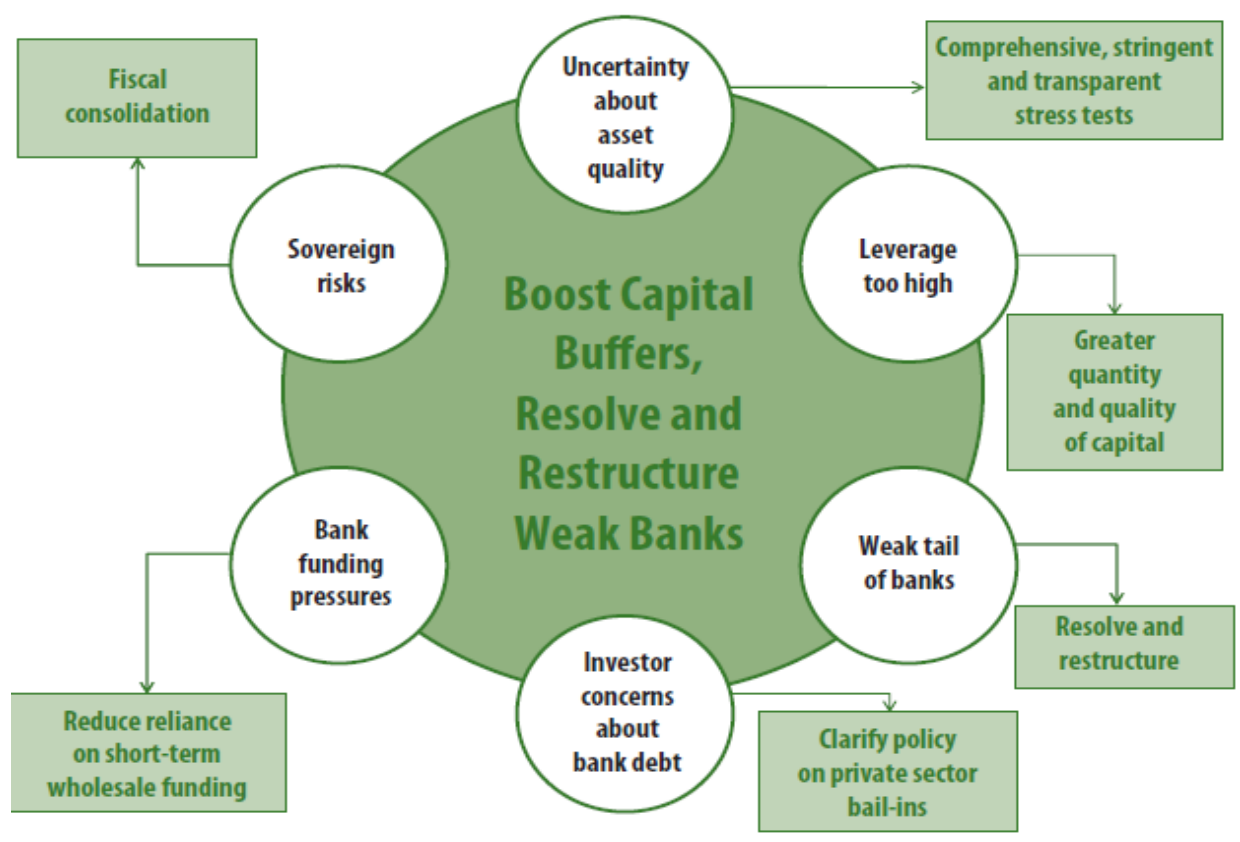

Source: IMF (2011)

\section{Innovation incentives, financial stability and the role of transparency}

A crucial function of the financial system is to assist in the better allocation and deployment of economic resources (both spatially and across time) in an uncertain environment. Such function consists of: (a) a payments system with an exchange medium; (b) the transfer of resources from savers to borrowers; (c) the gathering of savings; and (d) the reduction of risk through insurance and diversification. ${ }^{76}$

Practice demonstrates that several existing rules relating to the optimal diversification of risks, the protection of consumers and investors, capital adequacy, the avoidance of systemic risks or the assurance of market integrity can be regarded as ineffective. Recent scholarship has further cast doubt on the virtues of universal banking. ${ }^{77}$ The correctness of this latter view seems to be confirmed by current initiatives obliging banks to reassess their focus by divesting some of its holdings or abandoning certain financial activities. In addition, the shift towards non-traditional banking activities, sometimes through the creation of allegedly powerful financial conglomerates, was regarded as reducing banking system stability. Indeed, 'the usefulness of financial conglomeration as a risk diversification device' has been seriously questioned. $^{78}$ On the other hand, market discipline, which is a mechanism delegating to

${ }^{76}$ See R. Merton, 'Financial Innovation and Economic Performance' (1992) 4 Journal of Applied Corporate Finance 12.

${ }^{77}$ E. Avgouleas, 'Breaking Up Mega-Banks - A New Regulatory Model for the Separation of Commercial from Investment Banking' in Delimatsis and Herger (eds), above note 7. The Wall Street Reform and Consumer Protection Act (Dodd-Frank Act, which at the Senate changed into 'Restoring American Financial Stability Act'), which constitutes the US legislative response to the crisis, now includes the so-called 'Volcker Rule' (after the former Chairman of the Fed), which does not allow banks to invest more than 3\% of their Tier 1 capital in private equity and hedge funds, and trade for hedging purposes. This is a mild form of the prohibition of combined investment and commercial banking in the Glass-Steagall Act. Similar restrictions are foreseen for non-bank financial institutions supervised by the Federal Reserve.

${ }^{78}$ See O. De Jonghe, 'Back to Basics in Banking? A Micro-Analysis of Banking System Stability', European 
market participants the monitoring and disciplining of excessive risk-taking conduct and one of the Basel II pillars, has not pre-empted the current turmoil. ${ }^{79}$ To be sure, market discipline was distorted in part by the broad government guarantees that diminish any incentive for the stakeholders to monitor their banks. Interestingly, it seems that market monitoring worked fairly well across financial institutions in the same time period. ${ }^{80}$

Thus, it comes as no surprise that an important part of the current Basel III framework focused on the revision of the Pillar 3 requirements relating to, inter alia, securitization exposures and sponsorship of off-balance sheet vehicles. Banks are now required to disclose all elements of the regulatory capital base, the deductions applied and a full reconciliation to the financial accounts. In addition, banks are warranted to publish in their websites the full terms and conditions of all the instruments that are included in regulatory capital. As excessive remuneration in the financial sector has been considered as an important risk management weakness giving false incentives and has become a controversial theme in the public debate in the wake of the crisis, the BCBS brought forward a proposal on requirements for annual disclosure of remuneration practices to support an effective market discipline and to allow market participants to assess the quality of practices relating to compensation and the quality of support for the firm's strategy and risk posture. ${ }^{81}$ In this regard, banks are not merely requested to disclose the relevant information, but also to clarify how these factors complement and support their overall risk management framework. In the medium term, such requirements of quantitative and qualitative nature ${ }^{82}$ should promote greater convergence and consistency of disclosure regarding remuneration without requiring the disclosure of confidential business information.

\section{The current transparency provisions relating to financial innovations after the crisis}

The recent financial turmoil brought about several reforms in the regulation of financial services. Both in the EU and the US, important institutional changes have been adopted both at the macro- and micro-prudential level. In the EU, the new architecture for financial supervision consists of three new European Supervisory Authorities (ESAs): the European Banking Authority (EBA); ${ }^{83}$ the European Securities and Markets Authority (ESMA); ${ }^{84}$ and the European Insurance and Occupational Pensions Authority (EIOPA). ${ }^{85}$ At the macroprudential level, a European Systemic Risk Board (ESRB) is created to monitor and assess potential threats to financial stability, focusing notably on providing early warning signals about system-wide risks that may be building up. ${ }^{86}$ Thus, the ESRB assumes the responsibility for macro-prudential analysis which until recently was conducted in a fragmented manner. At the same time, a European System of Financial Supervisors (ESFS) was created. This is a network of financial supervisors which are active at the national level and at the EU level. At the level of the EU, the network consists of the ESRB and the three micro-supervisory ESAs. The ESAs will have a vital role in advising the Commission on the

\footnotetext{
Banking Center Discussion Paper No 2009-13S, Tilburg University (forthcoming in the Journal of Financial Intermediation).

${ }^{79}$ See C. Stephanou, 'Rethinking Market Discipline' in Delimatsis and Herger, above note 7.

${ }^{80}$ See M. Flannery, 'Market Discipline in Bank Supervision' in Berger; Molyneux; and Wilson (eds), above note 34, at 398 .

${ }^{81}$ See above note 74 .

${ }^{82}$ Ibid, pp. 3-5.

${ }^{83}$ Regulation 1093/2010, [2010] OJ L331/12.

${ }^{84}$ Regulation 1095/2010, [2010] OJ L 331/84.

${ }^{85}$ Regulation 1094/2010, [2010] OJ L 331/48.

${ }^{86}$ Regulation 1092/2010, [2010] OJ L 331/1.
} 
implementation of legislation and in drafting technical standards in those areas that the new or revised relevant Directives envisage. In this respect, it bears noting that the EU Commission is in the process of revising several important directives such as the Capital Requirements Directive, the Financial Conglomerate Directive or the Review of the Markets in Financial Instruments Directive (MiFID), also taking into account the Basel III framework that is emerging under the auspices of the BCBS. ${ }^{87}$

In the US, the Dodd-Frank Act brought about sweeping changes in the American financial system. The new framework aims to address regulatory loopholes in areas such as over-thecounter (OTC) derivatives, asset-backed securities (ABS), hedge funds, credit rating agencies, mortgage brokers and payday lenders. The Financial Stability Oversight Council (FSOC), attached to the Treasury Department and composed of federal financial regulators, will be tasked with identifying and responding to emerging risks throughout the financial system, notably by monitoring systemic risk posed by large financial firms and products or activities that spread risk across firms. The FSOC is also tasked with improving interagency cooperation. Crucially, the FSOC can, by a $2 / 3$ vote, (a) require that a non-bank financial service provider be regulated by the Federal Reserve (Fed) provided that its failure would risk financial stability; and (b) approve a Fed decision to require that a large complex firm divest some of its holdings if it poses a grave threat to the financial stability of the US. In addition, a new Office of Financial Research is created within Treasury to collect and analyze data to identify emerging risks and disclose relevant information in periodic public reports and Congress testimony. However, every regulation of banks will be divided among the Fed, the Federal Deposit Insurance Corporation (FDIC), and the Office of the Comptroller of the Currency (OCC). Finally, a Consumer Financial Protection Bureau (CFPB) is created to protect consumers from unfair and deceptive financial products and practices and ensure adequate disclosure of information. Overall, the competences of the Fed are strengthened in the wake of the crisis, which will, inter alia, oversee the larger, more complex holding companies with assets over $\$ 50$ billion and other systemically important financial companies. The Board of Governors of the Fed is now responsible for identifying, measuring, monitoring and mitigating risks to financial stability. In addition, several changes in the governance of the Fed are made to avoid conflict of interest, whereas the importance of the New York Federal Reserve Bank is recognized, leading to increased accountability for the latter.

\section{Hedge funds}

Hedge funds have been largely unregulated for a long period of time and thus were important actors of the shadow financial system. The G-20 has unequivocally pointed to the need for regulatory intervention in this area. This comes as no surprise as hedge funds sometimes manage a large quantity of assets on behalf of pension funds and other investors. Furthermore, they constitute a significant source of counterparty risk for other market participants and their contribution to building-up of leverage can be important, as shown by the recent turmoil.

In the EU, a new Directive on managers of alternative investment funds (AIFMD) is aimed at filling a gap as to the regulation of hedge funds. ${ }^{88}$ The Directive also covers private equity funds, real estate funds and various other types of institutional fund. As in the other areas that

${ }^{87}$ Cf. European Commission, 'Regulating financial services for sustainable growth - A progress report', February 2011, pp. 13-14.

${ }^{88}$ See Council of the European Union, 'Proposal for a Directive of the European Parliament and of the Council on Alternative Investment Fund Managers and amending Directives 2003/41/EC and 2009/65/EC', Revised Note, 6795/3/10 REV 3, 10 March 2010. 
we consider below, the EU aims to create single passports, in this case a single market passport for European managers and funds. In addition, a third-country passport is expected to become a harmonized regime for third-country access to EU investors, establishing mechanisms for the recognition of equivalence. However, the new Directive provides for a 5year transitional period, during which national regimes will co-exist with the EU framework. The Directive applies de minimis thresholds for its applicability: Funds with assets of less than $€ 100$ million are required to register with national authorities and to comply with harmonized transparency requirements and additional requirements applied at national level. Subject to full compliance with the Directive, such funds can opt in so as to benefit of the 'passport' regime.

The AIFMD includes several provisions that aim to enhance transparency in the sector and allow investors to perform better due diligence. For instance, each investment fund will be required to harness the leverage it uses and will be obliged to comply with the set limits on an ongoing basis. Competent authorities are to be informed about the use of leverage and the ESRB will have access to this information to prevent the build-up of systemic risk. If needed, the competent authorities will also be authorized to impose leverage limits under the coordination of ESMA. Furthermore, the AIFMD tackles conflicts of interest (disclosure or management); it ensures that the liquidity profile of a fund reflects the obligation towards investors; it requires that assets be safe-kept by an independent depositary subject to a high liability standard and that valuation be performed properly and independently. In addition, the new Directive limits investment in several types of alternative investment fund only to professional investors. Access for retail investors can only be granted through national legislation, but in this national authorities are to adopt additional safeguards at national level to guarantee consumer protection.

An important part of the financial reform in the EU relates to remuneration practices and the alternative funds are no exception. Annex II of the new Directive requires that funds adopt remuneration policies that, inter alia, be consistent with and promote sound and effective risk management without encouraging risk taking inconsistent with the risk profiles, fund rules or instruments or incorporation of the fund. Remuneration policies shall be consistent with the business strategy, objectives and values of the fund and shall be reviewed periodically.

In the US, the new regulatory framework created under the Dodd-Frank Act imposes strict regulatory requirements to hedge funds and other private funds for the first time. It requires that hedge funds managing over $\$ 100$ million register with the SEC as investment advisors and disclose financial data about their trades and portfolios necessary to monitor and assess systemic risk and ultimately protect investors. The Dodd-Frank legislation also attempts to harness the perilous ties between banks and hedge or private equity funds, for instance by limiting investment of banks in such funds. The same goes for the relationship of the latter with non-bank institutions supervised by the Fed. Such regulations seem to lead banks to look for 'hedge-like' investment vehicles in which they could invest money previously invested in hedge funds. Currently, an interesting development which may call for regulatory intervention in the immediate future is the growing convergence of practices between hedge funds and mutual funds. The latter, traditionally considered as conservative and more stable types of investment, appear to adopt more risky, hedge-like practices such as long-short strategies, market-neutral strategies and arbitrage strategies within the limits of federal securities laws. On the other hand, hedge funds start offering more conservative strategies such as equity long-only strategy, thereby mimicking strategies of mutual funds. Such developments blur regulators, as, depending on the facts, several regulations both at the federal and state level may come into play. For instance, mutual funds have been subject to the Investment Company Act of 1940 as amended, but also the Sarbanes-Oxley Act of 2002. Would the requirements of 
these laws apply cumulatively with the requirements of the Dodd-Frank Act relating to hedge funds in this type of hybrid situation? More importantly, quid in the case of conflict among these pieces of legislation? The more we see convergence among the abovementioned type of activities the more pressing these questions will become, raising issues of conflicting supervision and overlapping (over-)regulation. Such challenges allude to the pressing need for the adoption of function- rather than institution-based regulatory approaches when regulating financial services.

Finally, a source of possible concern can be that hedge funds managing less than $\$ 100$ million would act under State supervision. This means that possible conflicts can arise between the State regulators and the SEC, even if it was argued that State regulators may be more efficient and diligent regulators.

\section{Derivatives}

With respect to derivatives, the limited transparency of overall counterparty credit risk exposures caused a loss of confidence and negatively affected market liquidity in time of stress. ${ }^{89}$ For a long period, derivatives were deemed to be instruments for professional use, which justified their light regulation. Based on the negative experience with the collapse of Lehman Brothers and the meltdown of AIG, derivatives regulation came to the forefront of regulatory reform efforts in the financial sector. In the Pittsburgh Summit, the G-20 required that all standardized OTC derivative contracts be traded on exchanges or electronic trading platforms and cleared though central counterparties by end-2012. In addition, OTC derivative contracts will have to be reported to trade repositories and that non-centrally cleared contracts should comply with higher capital requirements.

OTC derivatives are derivatives which are traded and negotiated bilaterally, ie without going through an exchange or other intermediary. The OTC derivative market is the largest derivative market in terms of volume (almost $90 \%$ of derivatives is traded over the counter, growing from $\$ 91$ trillion in 1998 to $\$ 615$ trillion in end-2009) and has been free of any disclosure requirements with regard to prices, trading parties, time or underlying assets. However, it went unnoticed that derivatives allow leverage to increase and so do they with respect to the interconnectedness of market participants.

The objective has been twofold: to increase pricing transparency and to reduce bilateral or counterparty credit risk. In both sides of the Atlantic, determination for regulating OTC derivatives markets is evident. In the EU, the European Commission brought forward in September 2010 a proposal for a Regulation on OTC derivatives, central counterparties and trade repositories. ${ }^{90}$ The proposal introduces a reporting obligation for OTC trading; a clearing obligation for certain categories of OTC derivatives, measures to reduce counterparty credit and operational risk for bilaterally cleared OTC derivatives; common rules for central counterparties and trade repositories; and rules on the establishment of interoperability between CCPs.

More specifically, detailed information on OTC derivative trades entered into by both EU financial (such as banks, insurance companies, funds) and non-financial firms (eg energy companies, airlines, manufacturers) with large positions in the OTC derivatives market is to be reported ${ }^{91}$ to trade repositories and made accessible to supervisory authorities, whereas

\footnotetext{
${ }^{89}$ Cf. FSB, 'Implementing OTC Derivatives Market Reforms', 25 October 2010, p. 9.

${ }^{90}$ European Commission, 'Proposal for a Regulation of the European Parliament and of the Council on OTC derivatives, central counterparties and trade repositories', COM(2010) 484 final, 15 September 2010.

${ }^{91}$ An exception is foreseen for contracts between two non-financial firms where neither firm exceeds a certain
} 
trade repositories have to publish aggregate positions by class of derivatives, which shall be accessible to all market participants. CCPs are to face stringent rules on prudential (notably with regard to capital requirements), organizational and conduct of business standards (for instance, disclosure of prices). CCP clearing for contracts that have been standardized becomes mandatory, while risk mitigation standards such as exchange of collateral are foreseen for contracts not cleared by a CCP. To reduce operational risk, the use of electronic means for the timely confirmation of the terms of OTC derivatives contracts is warranted to allow counterparties to net the confirmed transaction against other transactions and ensure the accuracy of book keeping.

This legislative initiative is complemented with a proposal for a Regulation on short selling and credit default swaps (CDS). ${ }^{92}$ Within this framework, the ESMA is to play a crucial role notably with regard to the identification of contracts subject to the clearing obligation and the surveillance of trade repositories. The EU Commission is also in the process of revising several Directives that will affect OTC derivatives such as the Capital Requirements Directive, the Market in Financial Instruments Directive (to ensure trading of standardized contracts on organized trading venues, enhancing trade and pricing transparency across venue and OTC markets) and the Market Abuse Directive (extending its scope to OTC derivatives). ${ }^{93}$

Interestingly, the new Directive on undertakings for collective investment in transferable securities (UCITS) allows to such investment funds to invest in derivatives either as part of their general investment policy or for hedging purposes. ${ }^{94}$ Exposure to such instruments should not exceed the total net value of the portfolio of a UCITS. To ensure investor protection, full disclosure of the strategy vis-à-vis derivatives is warranted, according to the Directive, and notably with respect to OTC derivatives. ${ }^{95}$

The Wall Street Transparency and Accountability Act of 2010, as part of the Dodd-Frank comprehensive bill, attempts to achieve the two-fold objective notably with respect to OTC transactions. According to the Act, the SEC and the Commodity Futures Trading Commission (CFTC) are required to regulate OTC derivatives. The former shall exercise oversight over security-based swaps, whilst the latter is to supervise swaps in general. Clearing houses or swap repositories shall publish the collected data to improve market transparency and provide regulators the tools for monitoring and responding to risks.

To avoid circumvention, 'swaps' are defined very broadly to include, inter alia, interest rate swaps, caps and floors, $\mathrm{CDS},{ }^{96}$ total return swaps, weather swaps, energy swaps, equity swaps, equity index swaps, agricultural swaps, commodity swaps as well as any 'agreement,

information threshold. Nor should these contracts be cleared unless they exceed a certain clearing threshold. Such thresholds are to be established by the ESMA and the ESRB.

${ }^{92}$ European Commission, 'Proposal for a Regulation of the European Parliament and of the Council on Short Selling and certain aspects of Credit Default Swaps', COM(2010) 482 final, 15 September 2010.

${ }^{93} \mathrm{Cf}$. European Commission Communication, 'Ensuring efficient, safe and sound derivatives markets: Future policy options', $\mathrm{COM}(2009) 563$ final, 20 October 2009.

${ }_{94}$ See Directive 2009/67/EC of the European Parliament and of the Council on the coordination of laws, regulations and administrative provisions relating to undertakings for collective investment in transferable securities', [2009] OJ L 302/32.

${ }^{95} \mathrm{Ibid}$, Art. $50(\mathrm{~g}), 51$.

${ }^{96} \mathrm{CDS}$ are among the derivatives that continue to be at the heart of the current financial turmoil, this time relating to sovereign debt. CDS are derivatives which provide insurance against the risk of credit default of a corporate or government bond. For an annual premium, the buyer of a CDS is protected against the risk of default of the reference entity by the seller. If the reference entity defaults, the protection seller compensates the buyer for the cost of the default. CDS and short selling are now at the spotlight of regulators notably in the EU. 
contract, or transaction that is, or in the future becomes, commonly known to the trade as a swap'. 97 'Security-based swaps', on the other hand, are defined to include, inter alia, swaps based on either (i) a narrow-based security index, (ii) a single security or loan, or (iii) the occurrence, non-occurrence, or extent of the occurrence of an event relating to a single issuer of a security or the issuers of securities in a narrow-based security index, provided that such event directly affects the financial statements, financial condition, or financial obligations of the issuer. Mixed swaps, while essentially being security-based swaps, are to be regulated jointly by the SEC and the CFTC, after consultation with the Board of Governors of the Fed.

Importantly, the Act identifies specific categories of market participants/entities, which are to respect several obligations and, crucially, comply with certain capital and margin requirements as well as reporting and recordkeeping obligations. These are: swap dealers; security-based swap dealers; major swap participants and major security-based swap participants.

\section{Credit rating agencies (CRAs)}

CRAs relate to the issue of financial innovation in two important respects: first, they innovate themselves to improve, for instance, the accuracy of their data or the collection and processing of data which allow them to issue reliable credit ratings. Second, the rules that CRAs use may give rise to financial innovations, whereby rated financial institutions have strong incentives to invent financial tools which allow them to ameliorate, even if only artificially, their financial situation. ${ }^{98}$

CRAs issue opinions on creditworthiness of companies, governments and sophisticated financial instruments. There are about 150 CRAs, but only three of them (Standard and Poor's; Moody's; and Fitch) share some $95 \%$ of the market. ${ }^{99}$ For a long time, they were presumed to be the most reliable source of information with regard to the risk of specific financial products and enjoyed the privilege of self-regulation. The regulatory state has also contributed to this presumption already back in the $30 \mathrm{~s},{ }^{100}$ but also until recently as such credit rating were used in regulatory and supervisory practices. ${ }^{101}$ In addition, credit ratings were used as reference for the calculation of capital requirements for solvency purposes with which financial institutions had to comply.

In the wake of the financial crisis, their failure to adequately pinpoint the risk associated with subprime residential mortgage-backed securities (MBS) and collateralized debt obligations (CDOs) linked to such securities led to public outcry about the impartiality of CRAs and the conflicts of interest inherent in their activities notably because of the 'issuer

\footnotetext{
${ }^{97}$ Foreign exchange swaps and forwards (other than retail transactions) constitute swaps unless the Secretary of the Treasury makes a written determination that they should not be subject to regulation and they are not structured to evade the Act in violation of any CFTC rule.

${ }^{98}$ The latter alludes to the strong ties between financial innovation and legal engineering. See P. Tufano, 'Financial Innovation' in G. Constantinides; M. Harris; and R. Stulz (eds), The Handbook of the Economics of Finance, Volume 1A: Corporate Finance (Elsevier, 2003).

${ }^{99}$ See F. Amtenbrink and J. de Haan, 'Regulating Credit Rating Agencies in the European Union' in Delimatsis and Herger (eds), above note 7, p. 99.

${ }^{100}$ See L. White, 'The Credit Rating Agencies: Understanding Their Central Role in the Subprime Debacle of 2007-2008', 8 April 2009, p. 4.

${ }^{101}$ Cf. European Central Bank (ECB), ‘European Commission’s Public Consultation on Credit Rating Agencies - Eurosystem Reply', February 2011, available at:

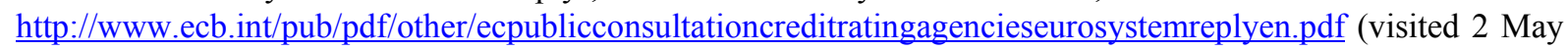
2011).
} 
pays' business model that was introduced in the early ' $70 \mathrm{~s} .{ }^{102}$ Indeed, a source of suspicion has been that, whereas CRAs have covered structured financial products for several years, they started downgrading such securities only once the crisis was already unfolding, ie from 2007 onwards. ${ }^{103}$ Coincidentally or not, CRAs profits exploded with the growth of such products. For instance, the profits of Moody's tripled between 2002 and 2006. ${ }^{104}$ Rules addressing conflict of interest; the quality of credit ratings; the transparency and internal governance of CRAs; the overreliance on credit ratings; ${ }^{105}$ and the supervision of their activities are deemed as adequate to remedy the situation. In the new regulatory frameworks that we examine below, a common theme is the requirement for more transparency and disclosure with regard to the methodologies, models and data used by CRAs. Thus, just as in previous innovative financial products, financial innovation in this field also is now to be regulated and supervised more closely as a result of the financial crisis, with supervisory bodies having direct access to previously undisclosed information.

In the EU, the Regulation 1060/2009 brings forth major changes in the credit rating business within the European Union. ${ }^{106}$ Most importantly, all CRAs which would like to have their credit ratings used within the EU are required to apply for registration following the procedure described in Title III of the Regulation and Annex II thereof. Such applications are to be treated by the Committee of European Securities Regulators (CESR), which is to be deciding in a college. The college of regulators is responsible for the supervision of CRAs. The CESR, which was re-established with the Commission Decision 2009/77/EC, ${ }^{107}$ is responsible for monitoring compliance of the registered CRAs with the Code of Conduct Fundamentals for CRAs adopted by the International Organization of Securities Commissions (IOSCO). However, application of this Code remains voluntary. ${ }^{108}$

It bears mention that, with the creation of the European Supervisory Authorities mentioned above, the competences with regard to supervision will change. With respect to CRAs, The ESMA will have exclusive supervisory powers as of 1 July 2011. The ESMA will be responsible for the processing of registration, ongoing supervision and for all matters regarding ratings issued by CRAs established in third countries that operate in the EU under the certification or endorsement mechanisms. Most likely, the ESMA will also have supervisory powers over trade repositories when the Regulation on OTC derivative markets is

102 Cf. US SEC, 'Summary Report of Issues Identified in the Commission Staff's Examinations of Select Credit Rating Agencies', July 2008, available at: http://sec.gov/news/studies/2008/craexamination070808.pdf (visited 2 May 2011).

${ }^{103}$ That CRAs only react when crises (including sovereign debt crises) are already underway may be a reccurring theme. In this respect, ratings behaviour can generate pro-cyclical forces. See C. Reinhart, 'Sovereign Credit Ratings Before and After Financial Crises' in R. Levich; G. Majnoni and C. Reinhart (eds), Ratings, Rating Agencies and the Global Financial System (Kluwer, 2002), 251.

${ }^{104}$ P. Bolton; X. Freixas; and J. Shapiro, 'The Credit Ratings Game', May 2010. Interestingly, the authors provide evidence suggesting that a monopoly CRA may be more efficient than any other solution and notably the current oligopoly, thereby providing support to those arguing that the creation of one CRA in Europe would be the optimal solution.

${ }^{105}$ The FSB has also developed a set of principles on this score. See FSB, 'Principles for Reducing Reliance on CRA Ratings', 27 October 2010.

${ }^{106}$ Regulation(EC) 1060/2009 of the European Parliament and of the Council on credit rating agencies, [2009] OJ L 302/1. Accoridng to Article 3:1(a) of the Regulation, credit rating is 'an opinion regarding the creditworthiness of an entity, a debt or financial obligation, debt security, preferred share or other financial instrument, or of an issuer of such a debt or financial obligation, debt security, preferred share or other financial instrument, issued using an established and defined ranking system of rating categories'.

${ }^{107}$ OJ L 25 of 29 January 2009, p. 18.

${ }^{108}$ IOSCO, 'Code of Conduct Fundamentals for Credit Rating Agencies', revised version of May 2008. The most recent Code is available at: www.iosco.org/library/pubdocs/pdf/IOSCOPD271.pdf. (visited 1 March 2011) 
adopted. This will allow for a centralized and more coherent oversight notably with respect to activities and entities with pan-European reach. National supervisors will remain in charge of supervision of the use of ratings by individual entities which are supervised at national level. However, the new proposal for a Regulation amending the current Regulation 1060/2009 implies a hierarchical relationship between the ESMA and the national supervisors in favour of the former for the issues relating to the application, enforcement and breach of the Regulation. ${ }^{109}$

Ratings issued in third countries can be used in the EU through two different mechanisms: first, through endorsement pursuant to Article 4:3 of the Regulation; and, second, through certification according to Article 5. In the latter, case one essential condition is that the European Commission adopts an equivalence decision with the third country, which recognizes the legal and supervisory framework of that third country as equivalent to the requirements of the Regulation, notably Articles 6-12. ${ }^{110}$ According to these provisions, registered CRAs have to adhere to strict rules to address conflicts of interest. CRAs are no longer allowed to carry out consultancy or advisory services, but only some ancillary services as long as they do not create conflicts of interest with the issuing of credit ratings. ${ }^{111}$ Moreover, Sections A and B of Annex I of the Regulation incorporate specific far-reaching requirements relating to the corporate governance of CRAs. Furthermore, the CRAs have to ensure the quality and accuracy of the methodologies, models and key assumptions they use. This requirement is accompanied by various transparency obligations, notably when it comes to structured finance products. CRAs are also expected to disclose regularly specific information and notify more sophisticated data to a central repository. In addition, CRAs are required to publish annual transparency reports on matters such as the legal structure and ownership of the CRA, a description of the internal control mechanisms ensuring the quality of credit ratings or financial information on the revenue of the CRA. ${ }^{112}$ To exemplify the stringency of the new regulatory framework, it is noteworthy that the Regulation attempts to harness outsourcing in this industry. Thus, outsourcing of important operational functions is prohibited if it impairs the quality of the internal control of the CRA and the ability of the supervisory authorities to verify compliance with the Regulation.

Currently, the European Commission leads a consultation phase in November 2010 to seek feedback on remaining issues relating to the regulation of CRAs. A first concern is the issue of continuing overreliance on credit ratings, as exemplified by the current euro debt crisis. Ensuring accurate and reliable sovereign debt rating is an associated matter that also forms part of these consultations. Other issues include whether: competition in the currently oligopolistic CRA industry should be enhanced; a civil liability regime for CRAs is needed; ${ }^{113}$ and, more critically, what alternatives to the 'issuer-pays' model exist which could

\footnotetext{
109 European Commission, 'Proposal for a Regulation of the European Parliament and of the Council on amending Regulation (EC) No 1060/2009 on credit rating agencies', COM(2010) 289 final, 2 June 2010. It is noteworthy that the prospective Regulation does alter the substantial requirements of the Regulation 1060/2009, but rather focuses on its amendment to reflect the centralization of the supervisory oversight of credit rating agencies after the creation of the ESMA.

${ }^{110}$ See, for instance, with respect to CRAs, the Commission's 'Decision on the recognition of the legal and supervisory framework of Japan as equivalent to the requirements of Regulation (EC) No 1060/2009 of the European Parliament and of the Council on credit rating agencies', [2010] OJ L 254/46, available at: http://ec.europa.eu/internal_market/securities/docs/agencies/japan_en.pdf (visited 2 May 2011).

${ }_{111}$ Ancillary services include market forecats, estimates of economic trends, pricing analysis and other data analysis as well as related distribution services. See Section B of Annex I of the Regulation 1060/2009, para 4.

${ }_{112}$ See Annex I, Section E, Part III of the Regulation.

113 The European Parliament is in favour of CRA's exposure to civil liability due to gross negligence or misconduct. See European Parliament, 'Report on credit rating agencies: future perspectives', A7-0081/2011, 23
} 
eliminate possible conflicts of interest. ${ }^{114}$ With respect to competition, the European Commission seeks comments as to the desirability and feasibility of creating a public EU CRA. In this regard, it was proposed that the ECB or certain central national banks could provide credit ratings for regulatory purposes. The reaction of the ECB was rather unenthusiastic. ${ }^{115}$

In the US, a reconsideration of the previous practice which de facto led to outsourcing the evaluation of creditworthiness of financial products towards private CRAs for several decades is under way. Conflict of interests and differentiation between structured and other financial products take centre stage. However, just as everywhere in the world, one of the most important challenges remains how to reduce the use of and reliance on credit ratings in regulations and supervision practices. ${ }^{116}$

In 2006, the Congress passed the Credit Rating Agency Reform Act, which however did not prevent mismanagement and erroneous ratings which gave false signals to financial markets. CRAs registered as such with the SEC are called Nationally Recognized Statistical Rating Organizations (NRSROs), which include some 10 CRAs, including the big three. The Dodd-Frank Act Establishes a new Office of Credit Ratings at the SEC to strengthen regulation of credit rating agencies. New rules for internal controls, independence, transparency and disclosure as well as penalties for poor performance are aimed to restore investor confidence. The new Office is expected to examine NRSROs at least once a year and make available to public the results of those reviews.

Just as the EU Regulation on CRAs, the Dodd-Frank Act requires that NRSROs disclose their methodologies and data relied on; the use of third parties for due diligence and their track record with regard to credit ratings. Furthermore, the Act equally encompasses important corporate governance reforms for NRSROs. ${ }^{117}$ The latter, for instance, are required to have an effective internal control structure as to the implementation of and adherence to policies, procedures and methodologies leading to the issuance of credit ratings. In addition, they have to submit an annual internal control report to the Office of Credit Ratings, just as within the EU. Moreover, ratings analysts are required to take qualifying exams and have continuing education.

The Act also requires that every federal agency review current regulations that require the use of an assessment of the creditworthiness of the security or money market instrument as well as any references to credit ratings in such regulations. In such cases, agencies are called upon to remove any reference to, or, worse, requirement of reliance on credit ratings. The more challenging part of this exercise is that the agencies, absent the possibility of referring to CRAs credit ratings, should come up with a standard of creditworthiness that they deem to be appropriate for the regulations at stake.

Interestingly, the Act establishes a lower standard of fault to successfully bring forward liability claims than the EU Regulation on CRAs. Thus, investors can sue CRAs for a

\footnotetext{
March 2011, para. 43.

${ }^{114}$ See European Commission, 'Public Consultation on Credit Rating Agencies', 5 November 2010, available at: http:/ec.europa.eu/internal_market/consultations/docs/2010/cra/cpaper_en.pdf. (visited 12 February 2011). It is noteworthy that more than two-third of total CRAs revenues is generated by the issuer-pays model.

${ }^{115}$ ECB, above note 101, p. 7.

116 See US Department of the Treasury, 'Financial Regulatory Reform - A New Foundation: Rebuilding Financial Supervision and Regulation', 2009, pp. 44-46, available at: http://www.treasury.gov/initiatives/wsr/Documents/FinalReport_web.pdf (visited 2 May 2011).

${ }^{117}$ As noted with the case of the EU, the principles identified by the FSB over CRAs (above note 105) appear to lead to important transatlantic convergence on those areas.
} 
knowing or reckless failure to conduct a reasonable investigation of the facts in a given case or to obtain analysis from a third source. In extreme cases, CRAs can be deregistered if they issue low-quality ratings over an extensive time period. Overall, SEC is tasked with proposing and implementing sets of rules in numerous issues relating to the conduct, regulation and supervision of CRAs. For instance, various amendments to the Credit Rating Agency Reform Act of 2006 were proposed and implemented the last three years by the SEC, also driven by the mandate included in the Dodd Frank Act. Contrary to the EU where ratings of structured finance products are to bear distinctive features according to the relevant Regulation, the SEC is still in the consultation phase with regard to the appropriate methodology of rating such products. This is a difficult area of credit ratings with manifest oligopoly characteristics, as the three main CRAs worldwide determine about $94 \%$ of the outstanding credit ratings for structured finance products. More generally, this matter, along with the conflicts of interest raised by the issuer/subscriber pays model, appear to be the most challenging for SEC, but also for any regulator who is in the process of reforming the regulation of CRAs domestically. ${ }^{118}$

As noted in the Dodd Frank Act, CRAs play a 'gatekeeper' role in the debt market that is functionally similar to the one that securities analysts play when they evaluate securities in the equity market or auditors who review firms' financial statements. Thus, heavy regulation is justified. ${ }^{119}$ It is argued that overreliance on credit ratings will be the central issue for the years to come. The transparency and disclosure obligations may be helpful in this respect. However, they may not be sufficient. This is because the behaviour of institutional investors entails some sort of rational herding. This means that institutional investors will be far more interested to align with the behaviour of the other institutional investors without paying much attention on due diligence and creditworthiness. Improving the incentive mechanisms in these areas through enhanced civil liability and elimination of the regulatory privilege associated with a high rating may have a positive impact that no transparency or disclosure requirement could generate. $^{120}$

\section{A Tentative Conclusion}

We attempted to map above the most important regulatory reforms which will have a probably varying impact on several innovative financial products that financial markets and investors have used in the last decades. Previously voluntary guidelines such as those relating to corporate governance endorsed by international bodies now become binding and regulators seek their rigorous enforcement. If one adds to this the Basel III requirements that are being adopted, major structural changes are expected in the industry, notably because the state has now a resolutely pro-regulation stance also in order to protect its interests as shareholder.

Demanding disclosure requirements may go hand in hand with the betterment of the resilience of a given financial market. Thus, the fact that the level of sophistication of a given transparency requirement is high should not be taken to imply that in the long-term financial market will become less stable or more volatile. Rather, transparent and easily comparable transparency regulations may actually improve the efficiency of financial markets. ${ }^{121}$

\footnotetext{
118 See SEC, 'Solicitation of Comment to Assist in Study on Assigned Credit Ratings', Release No. 34-64456; File No. 4-629, 10 May 2011, available at: http://www.sec.gov/rules/other/2011/34-64456.pdf (visited 20 May 2011).

${ }^{119}$ Dodd Frank Act, Subtitle C, H.R. 4173-497.

120 Cf D. Langevoort, 'Global Securities Regulation after the Financial Crisis' (2010) 13:3 Journal of International Economic Law 799, at 810-11.

${ }^{121}$ R. Levine, 'Finance, Growth, and Opportunity: Policy Challenges', 31 October 2009.
} 
However, one should not lose sight of the fact that transparency requirements should be accompanied by concrete enforcement tools for supervisory authorities. For instance, without such tools, information on exposures in credit derivative markets alone may not allow avoiding challenging instances of financial instability, notably when ones takes into account the important cross-border exposures in derivative markets. In this regard, clarity (or lack thereof) as to the delimitation of competences of the manifold institutions that have been created in recent times may affect and procrastinate effective enforcement.

However, the top-down approach just described is not necessarily the only option one can envisage. Persuasive calls for more transparency can also come by the side of investors who, in order to protect their investment or make a decision as to where to invest their money, may create new screening and evaluation methodologies of companies, including financial institutions. ${ }^{122}$ Thus, the drive for profit can generate substantial levels of transparency which will allow investors to direct their money to the most efficient companies and thus support innovation, which in turn sustains long-run growth. ${ }^{123}$ In that case, transparency would be taken care of by the private sector. Public sector interference would thus be unnecessary. A danger here is that the information gap among regulators, investors and financial institutions may be widened instead of getting diminished. Thus, some form of supervision may be needed to oblige financial institutions to disclose information. In that case, even if the regulator does not have the expertise to digest and decipher this type of information, profitseeking investors would have a profound interest in undertaking this type of exercise. Hence, instead of arguing for more regulation in financial innovations, it would make more sense to insist on the development of more reliable and efficient screening technologies. Regulators can have a decisive role in the development of such policies. ${ }^{124}$

Finally, at the institutional level, it will be interesting to see how domestic regulators and supervisory authorities will interact in practice with the FSB, which has assumed a leading coordination role at the international level with the eulogies of G20. Recall that during the Seoul Summit, the G20 reaffirmed 'the FSB's role in coordinating at the international level the work of national financial authorities and international standard setting bodies in developing and promoting the implementation of effective regulatory, supervisory and other financial sector policies in the interest of global financial stability. ${ }^{125}$ When the smoke from the financial and sovereign debt crises goes down, FSB would most likely have to deal with regulatory competition in financial markets.

\section{Transparency in the GATS}

The GATS still lacks a comprehensive framework to tackle non-discriminatory, but still excessively burdensome regulatory measures; subsidization; or anti-competitive practices,

${ }^{122}$ As Levine eloquently put it:

...legal and regulatory system that both facilitate and compel equity and debt holders to oversee the management of financial institutions create more efficient, competitive financial systems that foster economic prosperity. Or, put differently, growth-promoting financial intermediaries arise with a greater probability when governments refrain from enacting and implementing regulations that interfere with the ability and incentives of shareholders and creditors to monitor financial intermediaries. (emphasis added)

Ibid, pp. 4-5.

${ }^{123}$ See Levine and Michalopoulos, above note 28.

${ }^{124}$ Ibid.

${ }^{125}$ Seoul Summit, G20 Declaration, para 40. 
among others. A priori, this would suggest that the successful culmination of a complaint brought before the WTO adjudicating bodies which would challenge the big bulk of the measures taken to address the recent financial crisis appears highly unlikely. This is not necessarily worrisome if the manifold measures that have been adopted to promote financial recovery remain temporary, as the G20 leaders pledged in Pittsburgh in November 2009. It becomes, however, a source of concern in case that these measures distort competitive conditions in the marketplace for the coming years, giving advantages to certain institutions over others or rescuing unsustainable institutions whose situation was problematic already before the upsurge of the crisis. ${ }^{126}$ They can also have trade-distorting effects if they require withdrawal from activities abroad to support domestic lending. Other than violating the spirit of the non-discrimination principle, the quintessence of the GATT/WTO edifice, ${ }^{127}$ such a constellation gives an erroneous message to financial institutions and may perpetuate moral hazard.

The tempting proposal for a complete overhaul of financial regulation which will be underpinned by a coherent intellectual framework ${ }^{128}$ is also relevant for the future role of the GATS in affecting the way financial services regulation will look like in the years to come. Being a central feature of the WTO, the GATS is based on the principles of nondiscrimination and progressive liberalization of market access. More specifically with respect to financial services, the GATS contains rules that are relevant for our purposes in three different instruments: First, in the GATS main text; second, the Annex on Financial Services, which forms an integral part of the GATS by virtue of Article XXIX GATS and therefore is binding to all WTO Members; and, third, the Understanding on Commitments in Financial Services (hereinafter, 'the Understanding'). The last two instruments elaborate on various provisions of the GATS, for instance, by increasing the level of sophistication or modifying certain provisions regulating trade in services in favour of more trade liberalization at the sectoral level. Transparency at a sectoral level does not seem to have been of major concern for the drafters of the GATS. Unlike the sectoral initiative on telecommunications, the Financial Services Annex does not incorporate any rules which would give some flesh to or require higher levels of notification or disclosure when compared to Article III GATS, which encompasses the main transparency obligations in the area of services trade. ${ }^{129}$ Furthermore, even in the current state of affairs, respect of the publication and notification requirements of Article III less than meets the eye. For instance, in its Trade Policy Review in 2008, the United States pointed out, in reply to a question from China, that few Members had recently notified under these provisions. Thus, from the US perspective, 'the absence of Article III:3 notifications would not appear to support a conclusion that they have neither introduced nor changed existing measures in a manner that significantly affects trade in services covered by their specific commitments'. ${ }^{130}$ Tellingly, none of the bail-out initiatives in the banking sector taken by many Members in 2007-08 had been notified by April 2009. To be sure the fact that some of these measures could possibly be justified under the prudential carve-out ${ }^{131}$ included in the GATS does not release any Member from its obligation to notify such measures to the

\footnotetext{
${ }^{126}$ Cf European Commission, 'Temporary Community framework for State aid measures to support access to finance in the current financial and economic crisis' OJ C 83/1 of 7 April 2009.

127 cf. Thomas Cottier and Markus Krajewski, 'Which Role for the Non-Discrimination Principle in International Financial Law?' (2010) 13:3 Journal of International Economic Law 817.

${ }^{128}$ See Franklin Allen; Ana Babus; and Elena Carletti, 'Financial Crises: Theory and Evidence', 8 June 2009, p. 31.

${ }^{129}$ For an analysis of Article III of the GATS, see P. Delimatsis, International Trade in Services and Domestic Regulations: Necessity, Transparency, and Regulatory Diversity (Oxford University Press, 2011), at 265.

${ }^{130}$ WTO document WT/TPR/M/200/Add.1 of 9 September 2008, at 213.

${ }^{131}$ See below note 144 .
} 


\section{WTO in accordance with Article III:3 GATS. ${ }^{132}$}

The only detailed rule pertaining to transparency in financial services is enshrined in paragraph B.1 of the Understanding, which requires that each Member that endorsed the Understanding list in its Schedule any existing monopoly rights relating to financial services. This provision includes a best-effort call for Members to eliminate such monopolies or reduce their scope. Other than this, the GATS does not interfere with the disclosure requirements adopted elsewhere, notably at the BCBS level, but rather adopts a neutral stance. However, it is commonplace that transparency is an important factor for good regulatory governance ${ }^{133}$ and may even influence supply patterns. ${ }^{134}$ That is, absent sufficient levels of transparency, a financial service supplier may opt for cross-border supply (Mode 1 in the GATS parlance) to the detriment of investment in financial services (mode 3 in the GATS parlance) may be discouraged.

The GATS, when compared to the other WTO Agreements, is a flexible contract whereby the main liberalizing provisions, that is, the elimination of limitations on market access (mostly of quantitative nature) ${ }^{135}$ and on national treatment, ${ }^{136}$ apply only if a given Member decides to open a given sector (such as financial services) or sub-sector (eg payment services) by inscribing a commitment in its Schedule of Commitments. Thus, it is the latter that determines the applicability of the most essential GATS rules to a given WTO Member. In this Schedule, when inscribing a sector or subsector, Members are expected to qualify the access granted to their domestic market or the remaining limitations with regard to national treatment.

With respect to scheduling commitments exclusively in financial services, the

${ }^{132}$ Accrording to Art. III:5 GATS, a reverse notification, ie a Member notifying another Member's measures that significantly affect trade in services, could also be possible. See P. Delimatsis, 'Article III: Transparency' in R. Wolfrum; P.-T. Stoll; and C. Feinäugle (eds), WTO - Trade in Services: Max-Planck Commentaries on World Trade Law (Martinus Nijhoff Publishers, 2008), at 99ff.

${ }^{133} \mathrm{Cf}$ at W. Dobson, 'Financial Services and International Trade Agreements: The Development Dimension' in A. Mattoo; R. Stern; and G. Zanini (eds), A Handbook of International Trade in Services (Oxford University Press, 2008) 289, at 297.

${ }^{134}$ P. Delimatsis, 'Due Process and "Good" Regulation Embedded in the GATS - Disciplining Regulatory Behaviour in Services Through Article VI of the GATS' 10:1 Journal of International Economic Law (2007) 13.

${ }^{135}$ The six market access limitations on market access set out in Art. XVI GATS are: a) limitations on the number of services suppliers (e.g. monopolies or exclusive rights for the supply of reinsurance services; measures limiting the number of bank licenses that will be granted); b) limitations on the total value of service transactions or assets (e.g. measures limiting foreign banking assets to a specific percentage of total banking assets in the Member concerned); c) limitations on the total number of service operations or on the total quantity of service output (e.g. limitations on the number of ATMs or branches that foreign banks can establish); d) limitations on the total number of natural persons that may be employed in a particular service sector or that a service supplier may employ (e.g. limitations on the number of foreign employees in banking institutions); e) measures which restrict or require specific types of legal entity or joint venture through which a service supplier may supply a service. This would capture, for example, not only non-discriminatory measures requiring specific types of juridical person to supply financial services (e.g. joint-stock companies), but also prohibitions to establish direct branches; or requirements that foreign insurance companies establish joint-ventures with local partners at the territory of the host Member; and f) limitations on the participation of foreign capital in terms of maximum percentage limit on foreign-shareholding or the total value of individual or aggregate foreign investment (e.g. measures prohibiting foreign investors from owning more than a specific percentage of the shares of asset management companies in the Member making the commitment).

${ }^{136}$ Contrary to market access, the national treatment obligation laid down in Art. XVII GATS does not enumerate limitations in an exhaustive manner, thereby allowing host countries to scheduel any type of discriminatory measure to the detriment of foreign service suppliers. 
Understanding provides an à la carte approach to scheduling. ${ }^{137}$ With its predetermined set of commitments it has led to deeper commitments in the sector and was incorporated into the Schedules of Commitments of several (notably OECD countries) Members on an MFN basis. ${ }^{138}$ The Understanding does not prevent a Member from adding any limitations on market access and/or national treatment even if it undertook commitments in the financial sector based on the Understanding. First, the Understanding requires the binding of the status quo and embodies a standstill commitment. That was an important feature, as several Members hesitated to bind the status quo of their domestic regulatory framework in most services sectors. Second, the Understanding has adopted a negative-list approach to scheduling regarding commitments on commercial presence. ${ }^{139}$ More specifically according to paragraph B.5, Members are required to grant financial service suppliers of other Members the right to establish or expand within their territory a commercial presence, even if this is done through the acquisition of existing companies. Paragraph B.6 allows Members to impose terms and conditions only as long as they do not circumvent Members' obligation under paragraph 5. Third, the Understanding signalled the importance of undertaking broad liberalisation commitments relating to market access, national treatment and government procurement. ${ }^{140}$

For our purposes, there are two interesting provisions in the Understanding: in paragraph B.3, the Understanding requires that Members allow cross-border trade in insurance services and the provision and transfer of financial information and financial data processing and advisory and other auxiliary services (but not intermediation) relating to banking and other financial services. Thus, in principle, several Members pledged to allow cross-border provision of various financial services. Furthermore, the Understanding refers to the concept of 'new financial service' for the first time, requiring Members to accept the supply of such services in their territory by any financial service provider established in the host country. ${ }^{141}$ The purpose of this provision, which was strongly supported by the U.S. financial services industry, is to allow innovative products introduced by financial institutions in their home countries - and approved by the competent home-country authorities - also to be introduced by their offices in the host countries regardless of whether these services are yet supplied in these jurisdictions. ${ }^{142}$ According to paragraph D.3, a new financial service is a service of a financial nature, including services related to existing and new products or the manner in which a product is delivered, that is not supplied by any financial service supplier in the territory of a particular Member but which is supplied in the territory of another Member. It is

\footnotetext{
${ }^{137}$ From a legal viewpoint, the Understanding is a unique WTO document, as it was included in the Final Act of the Uruguay Round but, does not form an integral part of the GATS.

138 The following Members undertook commitments according to the Understanding: Australia, Bulgaria, Canada, Czech Republic, European Communities (EC15), Hungary, Iceland, Japan, Liechtenstein, New Zealand, Nigeria, Norway, Slovak Republic, Sri Lanka (excluding insurance), Switzerland, Turkey, and United States.

139 According to paragraph 3.2 of the Understanding, commercial presence is defined more broadly than the GATS to mean any enterprise within a Member's territory for the supply of financial servcies and to include wholly-or partly-owned subsidiaries, joint ventures, partnerships, sole proprietorships, franchising operations, branches, agencies, representative offices or other organizations.

${ }^{140}$ In the case of government procurement and unlike Art. XIII GATS, Members that undertook commitments according to the Understanding pledged to ensure non-discrimination with respect to the purchase or acquisition of financial services by public entities at the host Member.

${ }^{141}$ Paragraph B.7 of the Understanding.

${ }^{142}$ As von Bogdandy and Windsor put it, 'this provision preserves the competitive advantage of innovative financial institutions in foreign and more traditional markets by preventing the host Member from inhibiting innovation'. See A. von Bogdandy and J. Windsor, 'Understanding on Commitments in Financial Services' in Wolfrum; Stoll; and Feinäugle (eds), above note 132, at 657.
} 
noteworthy that this provision has been replicated in several free trade agreements. ${ }^{143}$ Thus, the new financial services must not necessarily be supplied in the territory of the Member wishing to introduce it. Both of these provisions become pertinent in the wake of the financial crisis, notably when juxtaposed to the prudential carve-out reflected in paragraph 2(a) of the Financial Services Annex. ${ }^{144}$ The broad wording of the latter provision appears to imply that it prevails over any provision to the contrary, including terms, conditions and qualifications in the Schedules of Commitments that were inscribed according to the Understanding. However, such primacy can only be ascertained after a careful examination on a case-by-case basis, taking into account all parameters of a given measure affecting financial services supply.

It follows that the GATS rules become pertinent mainly after the identification of certain protectionist actions by a WTO Member and an examination of its Schedule of Commitments. The fact that WTO Members made more commitments in the financial sector than in any other sector except tourism makes a disagreement over the compatibility of a given measure with a Member's Schedule rather likely. The content of several measures mentioned above (for instance, the registration requirements for CRAs) may be actionable based on the abovementioned provisions, in conjunction with the obligations enshrined in the GATS, most pertinently on market access, national treatment and transparency. In the WTO, it is noteworthy that protectionism is considered to have occurred if the conditions of competition in the marketplace are distorted. Thus neither protectionist intent nor effect needs to be proven for a violation of the WTO obligations of a given country to be substantiated.

While in the immediate aftermath of the crisis protectionist pressures were minimal, in the most recent monitoring report released jointly by the WTO, OECD and UNCTAD an increase of potential protectionist measures was found. ${ }^{145}$ This report also confirms that less than $20 \%$ of the measures taken by G20 economies since October 2008 and were considered as problematic from a WTO law perspective were removed. Having said this, the situation is mixed in the area of services. For instance, market access has improved in the telecommunications sector. As to financial services, the report acknowledges that the supply of financial services by foreign financial institutions will become more difficult if only due to the stricter regulation and supervision of financial services, notably in the EU and the US, and a renewed focus on the adequacy of home country rules which may be negatively affecting the liquidity, operations or overall performance of institutions established in the host country. In the area of reinsurance, important restrictions to the cross-border supply of such services were introduced in Mexico, Argentina and Brazil. Traditionally, reinsurance is one of those financial services which have been supplied overseas by the big financial centers. ${ }^{146}$ As noted earlier, the Understanding provides that reinsurance and retrocession and the services auxiliary to insurance as referred to in subparagraph 5(a)(iv) of the Financial Services Annex is one of the areas where Members must allow for cross-border supply. ${ }^{147}$ The fact that those

\footnotetext{
${ }^{143}$ See, for instance, Chapter 7, Art. 3 of the Japan-Peru Economic Partnership Agreement.

${ }^{144}$ Paragraph 2(a) of the Financial Services Annex reads:

Notwithstanding any other provisions of the Agreement, a Member shall not be prevented from taking measures for prudential reasons, including for the protection of investors, depositors, policy holders or persons to whom a fiduciary duty is owed by a financial service supplier, or to ensure the integrity and stability of the financial system. Where such measures do not conform with the provisions of the Agreement, they shall not be used as a means of avoiding the Member's commitments or obligations under the Agreement. (emphasis added)

145 See WTO; OECD; UNCTAD, 'Report on G20 Trade Measures (Mid-October 2011-April 2011)', 24 May 2011, p. 7.

${ }^{146}$ WTO, 'Financial Services', S/C/W/312, 3 February 2010, p. 39.

${ }^{147}$ See Understanding on Commitments in Financial Services, Section B, para 3 (b).
} 
countries have not undertaken commitments based on the Undertaking gives them more flexibility in modifying their regulatory framework in the aftermath of the crisis. Nevertheless, this is not the case for those Members that used the alternative approach proposed by the Undertaking. For those countries, the invocation of the prudential carve-out laid down in the Financial Services Annex appears to be the only option for them to save their measures.

In the meantime, one cannot help but underscore Members' reluctance in reviewing the GATS and international trade regulation in financial services in the aftermath of the crisis with a view to adapting the legal framework to the new landscape. ${ }^{148}$ Manifestly, WTO Members do not consider the GATS as being in need of revision as long as the more relevant finance-related institutions at the global level such as the FSB, the BIS or the IMF are strengthened and adequate institutional reform takes place in this front. A more promising area where the GATS could perhaps play a role is standardization. However, à la the Agreement on the application of sanitary and phytosanitary measures (SPS), Members appear to consider that other institutions such as IOSCO are much more suitable to deliver in this area. Still, where the WTO could do more, along with its cooperation and information exchange policy, is the democratization in the form of more open participation and the increase of legitimacy of these institutions.

As things stand, the obligations enshrined in Article VI:1 may be the only available route in the GATS with some 'bite'. This provision requires that measures of general application affecting trade in services be administered in an objective, reasonable, and impartial manner. ${ }^{149}$ Whereas this obligation is conditional on the existence of specific commitments in the Schedule of a given Member, the fact that the commitments undertaken in the financial sector (notably by developed countries, which are now at the epicenter of recovery schemes) are sweeping clearly suggests that this obligation may have significant ramifications. A possible development of this requirement towards a requirement of objectivity, impartiality and reasonableness of the measures as such (as opposed to their administration) should be contemplated, although such a test is arguably enshrined already in the prudential carve-out of the Financial Services Annex.

In a nutshell, absent any concrete output and determined action by the WTO legislative, the scope of various GATS provisions relating to transparency remains vague. Nevertheless, from a normative point of view, in the case of financial services, leaving to other institutions the creation and implementation of a strategy for effective supervision, regulation and stability appears to be a type of wise outsourcing. Other than being a state-to-state contract that fails to capture this type of private activity in global finance, the WTO does not have the expertise to be actively involved in the discussion of how financial regulation or substantive regulatory standards will resemble in the coming years. ${ }^{150}$ Through the GATS, the WTO merely creates a procedural framework for regulatory cooperation. ${ }^{151}$ Furthermore, the political will appears to be in favour of managed multilateral constructions such as the upgrade of the FSB or the IMF which, albeit more inclusive than in the past in terms of membership, do not involve the

\footnotetext{
${ }^{148}$ See, more recently, Committee on Trade in Financial Services, 'Report of the Meeting Held on 9 March 2011', S/FIN/M/67, 12 April 2011.

${ }^{149}$ Delimatsis, above note 134; also Markus Krajewski, 'Article VI GATS (Domestic Regulation)' in Wolfrum; Stoll; and Feinäugle (eds), above note 132, 165.

${ }^{150}$ This is so even if the Committee on Trade in Financial Services is the only sector-specific committee in the services realm.

${ }^{151}$ See Mahmood Bagheri and Chizu Nakajima, 'Optimal Level of Financial Regulation Under the GATS : A Regulatory Competition and Cooperation Framework for Capital Adequacy and Disclosure of Information' (2002) 5:2 Journal of International Economic Law 507, at 524.
} 
WTO. Still, the link between global trade and finance is undoubtedly strong. Periodic reviews of current measures affecting trade that are published jointly by the WTO, the OECD and UNCTAD and communicated to G20 are aimed to increase awareness of this link. ${ }^{152}$

\section{E. Conclusion}

A substantial part of the blame for the crisis is put on the lack of transparency that was associated with the massive issuance of ABS, such as MBS and CDO. ${ }^{153}$ The sale of risky products to poorly-informed investors who ignored the risk they were taking of this type led to financial turmoil. New legislation on transparency requires the disclosure of more information about the underlying assets and an analysis of their quality. Such information, however, will be of no value if it cannot be processed adequately and expeditiously by the regulators, supervisors and investors alike.

Innovation in finance takes typically the form of evolutionary adaptations of prior products. ${ }^{154}$ This does not alter the fact that, just as every innovation, innovation in financial services is costly and risky. ${ }^{155}$ To all intents and purposes, financial innovation appears to finally be getting the attention that it deserves from the regulators' and supervisors' side. Tellingly, in a controversial move, the SEC created in September 2009 the Division of Risk, Strategy and Financial Innovation, the first new division created at the SEC in 37 years. This is a think-tank which is expected to improve the expertise of SEC in properly evaluating systemic risk and complex financial instruments and suggest regulatory solutions which would leave the appetite for further financial innovation untouched. This comes as a reaction to the fact that supervisors have been accused of being unable to understand the mechanics of financial innovation or of at least tolerating certain anomalies in areas such as the issuance of credit ratings, the function of derivatives markets or the conduct of hedge funds. ${ }^{156}$ Politicians have also been intermingling with financial decisions and encouraged the use of innovative financial instruments which contributed to the housing market bubble in the US and led to the enormous bailouts of Freddie Mac and Fannie Mae. ${ }^{157}$

The interaction between regulation and financial innovation is fairly peculiar: whereas product innovation would usually presuppose the existence of certain regulatory instruments such as subsidies to capital investment; R\&D subsidies; or tax credits, financial innovation appears to have its own dynamics. Incentives for financial innovation are mainly generated by the quest for expertise and the reputation therefor, as noted earlier. This means that there are hardly any regulatory incentives which could encourage financial innovation other than the

\footnotetext{
${ }^{152}$ See above note 145 .

${ }^{153}$ See A. Lehnert, 'Residential Mortgages' in Berger; Molyneux; and Wilson (eds), above note 34, at 588.

${ }^{154}$ Tufano, above note 98 . Compare the observation by Kline and Rosenberg that 'it is a serious mistake to treat an innovation as if it were a well-defined, homogenous thing that could be identified as entering the economy at a precise date - or becoming available at a precise point in time... The fact is that most important innovations go through drastic changes in their lifetimes - changes that may, and often do, totally transform their economic significance. The subsequent improvements in an invention after its first introduction may be vastly more important, economically, than the initial availability of the invention in its original form'. S. Kline and N. Rosenberg, 'An Overview of Innovation' in R. Landau and N. Rosenberg (eds), The Positive Sum Strategy: Harnessing Technology for Economic Growth (National Academy Press, 1986), 275, at 283.

${ }^{155}$ P. Tufano, 'Financial Innovation and First Mover Advantages' (1989) 25 Journal of Financial Economics 213.

${ }^{156}$ Levine, above note 121, p. 5.

${ }^{157}$ See also C. Calomiris, 'Financial Innovation, Regulation, and Reform', (2009) 29:1 Cato Journal 65, at 68, 85.
} 
protection of intellectual property rights, for instance, when it comes to the protection of sophisticated software programmes for assessing risk or screening start-ups with a view to deciding whether financing will be provided. In this area of innovation the general observation that competition will enhance innovation holds true. ${ }^{158}$ As noted earlier, it is rather this quest for acquiring first-mover advantage that leads financial institutions to invest in innovation. In addition, regulation can also encourage innovation - albeit of dubious social value - in that financial institutions may seek the use of financial innovations to avoid being regulated or taxed heavily. As we noted earlier, there is evidence suggesting that financial innovation has invariably been a response to regulatory intervention. Regulation can also encourage innovation in globalized financial markets if it seeks to harmonize certain requirements across jurisdictions such as reporting requirements, thereby diminishing compliance costs and facilitating market access. This is yet another example of the essential interplay between regulation, financial innovation and transparency, notably in a globalized financial landscape.

On the flip side of the coin, the regulatory environment can stifle innovation. For instance, it is expected with great interest the assessment of the effects of the Volcker rule that we described above, but also, more generally, of the reversal of light-touch regulatory approach that was dominating in the pre-crisis environment. There is evidence, albeit not compelling, that regulatory intervention can have negative effects on the creation of innovative financial products. ${ }^{159}$ However, this can be regarded as a welcome development if financial innovation merely aims at regulatory evasion. In this respect, financial innovation in recent decades, by crossing national borders, has affected regulation in that it has clearly made a compelling case for centralization of regulatory solutions and if possible global coordination of financial regulations to level the playing field. In such cases, enhanced transparency, a central goodgovernance principle, and sharing information across borders can allow for well-meant regulatory competition and ultimately encourage innovation, while allowing for better supervision and informed investment decisions. In the period before the crisis, global coordination has been the exclusive domain of private bodies such as the BIS or IOSCO. In the wake of the crisis, such total deference to a type of global self-regulation is being screened by the G20, whereas the calls for more open participation in the FSB are becoming more pressing. This should not be taken to mean that self-regulation, be it at domestic, supranational or international level, is abandoned. This is because information asymmetries between regulators and the market will not cease to exist. ${ }^{160}$

Another interesting interrelation that deserves further research is the one between competitiveness and transparency/disclosure requirements for financial innovative products. Take the case of derivatives markets. Requiring public disclosure of certain information such as position taking to certain contracts may ultimately have negative effects and may even reduce market liquidity. Therefore, it seems that disclosure exclusively to the corresponding regulator or supervisory authority would be much more meaningful. Public disclosure can still be required, but perhaps in a later date so that it does not affect business decisions nor allows for misuse of disclosed information.

Financial innovation is very much linked to globalization. If one considers the latter as an

${ }^{158}$ Cf. P. Aghion; N. Bloom; R. Blundell; R. Griffith; P. Howitt, 'Competition and Innovation: An Inverted-U Relationship' (2005) Quarterly Journal of Economics 701.

${ }^{159}$ Cf. L. White, 'Technological Change, Financial Innovation, and Financial Regulation in the U.S.: The Challenges for Public Policy', May 1997, p. 27.

${ }^{160}$ See N. Moloney, 'Financial Services and Markets' in R. Baldwin; M. Cave; and M. Lodge (eds), The Oxford Handbook of Regulation (Oxford University Press, 2010) 437, at 449. 
irreversible process, then financial innovation will continue to play a central role in the aftermath of the crisis. ${ }^{161}$ At an international level, we are witnessing a paradigm shift: economic globalization has outpaced the development of the political institutions required, as increased interdependence beyond borders also requires collective action beyond the national level. ${ }^{162}$ A hardening of the traditionally soft financial regulation at a global level is emerging with the upgrade of the FSB and the IMF. The fact that G20 substitutes for G8 as the forum of global discussions on economic recovery is a welcome development, as it broadens the group of countries which are heard. However, political legitimacy remains an issue. In any event, there is a high level of learning-by-doing in this area and we are at the beginning rather than the end of changes in the global financial architecture.

All regulatory efforts at the domestic and international level lean towards the adoption of strict, counter-cyclical regulations. The impact on financial innovation may vary. Innovative financial instruments that aim to circumvent regulation (that is, avoid heavy taxation or take advantage of regulatory arbitrage) may be addressed by such efforts. If so, this is a welcome development, as the broader, aggregate welfare effects of such innovations are doubtful at best. What is, however, more interesting and may have a significant impact on the future of finance is how securitization will evolve in the aftermath of the crisis and the strong proregulatory, 'hands-on' bias. As things stand, it seems that securitization has not lost its attractiveness and thus it is for the supervisors and regulators to ensure that a proper use of such instruments is made. Thus, the idea sometimes put forward that more regulation may impede innovation may not hold true: better regulation may direct entrepreneurial talents to financial innovations that enhance societal wellbeing.

\footnotetext{
${ }^{161}$ Cf. J. Trachtman, 'The International law of Financial Crisis: Spillovers, Subsidiarity, Fragmentation and Cooperation' (2010) 13:3 Journal of International Economic Law 719, at 729.

${ }^{162}$ Cf Goodhart and Lastra, above note 69, at 714.
} 